\title{
Using biochemical and isotopic tracers to characterise organic matter sources and their incorporation into estuarine food webs (Rufiji delta, Tanzania)
}

Dativa Shilla and J oyanto Routh

The self-archived postprint version of this journal article is available at Linköping University Institutional Repository (DiVA):

http:/ / urn.kb.se/ resolve?urn=urn:nbn:se:liu:diva-143381

N.B.: When citing this work, cite the original publication.

This is an electronic version of an article published in:

Shilla, D., Routh, J., (2017), Using biochemical and isotopic tracers to characterise organic matter sources and their incorporation into estuarine food webs (Rufiji delta, Tanzania), Chemistry in ecology, 33(10), 893-917. https:// doi.org/ 10.1080/ 02757540.2017.1391796

Original publication available at:

https:/ / doi.org/ 10.1080/02757540.2017.1391796

Copyright: Taylor \& Francis (STM, Behavioural Science and Public Health Titles) http:// www.tandf.co.uk/journals/ default.asp 


\title{
Using biochemical and isotopic tracers to characterize organic matter sources and their Incorporation into Estuarine food webs (Rufiji Delta, Tanzania)
}

\section{Dativa Shilla*, Joyanto Routh ${ }^{\mathrm{b}}$}

a Dar es Salaam University College of Education, Box 2329 Dar es Salaam, Tanzania

${ }^{\mathrm{b}}$ Department of Thematic Studies - Environmental Change, Linkoping University, SE 58183, Sweden

\begin{abstract}
Max 200 words)
Fatty acid biomarkers and stable isotope signatures were used to identify the sources of particulate and sedimentary organic matter and its input into the food web through the dominant consumer within the mangrove dominated Rufiji estuary, Tanzania. Specific fatty acids were used to identify the preferred basal sources of dominant fauna (i.e., filter feeder bivalves, snails, crabs, shrimps and three fish species), and their presence in the water and sediment samples in the estuary. Both fatty acid and stable isotope results revealed that food web in the Rufiji estuary depended on a variety of carbon sources (mangroves, allochthonous terrestrial inputs, macroalgae, and phytoplankton), contributing to a different degree into the diets of primary consumers and members of near-shore fish, but none of them were obligatory for the survival of these species. The $\delta^{15} \mathrm{~N}$ values of major primary producers and consumers/predators revealed a trend for $\delta^{15} \mathrm{~N}$ enrichment with increasing trophic level. The ratio of docosahexaenoic acid to eicosapentaenoic acid (DHA:EPA) decreased from pelagic to benthic feeding fish. This indicated that fish with different feeding modes derived their fatty acids from different primary sources of nutrition, and suggested that the DHA:EPA ratio may be a useful indicator of feeding mode.
\end{abstract}

Key words: Fatty acid, stable isotopes, organic matter, food web, Rufiji estuary.

*Corresponding author: sopdatty@gmail.com, Tel : +255 787 409846, Dar es Salaam University College of Education, Box 2329, Dar es Salaam, Tanzania.

\section{Introduction}


Estuaries have the potential to play an important role in the global carbon cycle through the exchange and modification of materials transported from land to coastal waters [1,2]. The organic matter (OM) pool in these systems comprises a spectrum of dissolved, colloidal and particulate material originating from a variety of sources. Foremost among these are terrestrial river-borne compounds, including those produced in the river itself or originating from the surrounding watershed, deriving from atmospheric fall out, industrial and municipal discharges, and marine-derived OM from adjacent coastal waters. The relative importance of these sources varies between and within estuaries [3-6]. Moreover, the composition and reactivity of OM delivered from different sources may also vary significantly, and consequently influence a number of key environmental processes such as the supply of food to benthic and pelagic organisms, water chemistry, sediment cohesiveness and stability, and the distribution of contaminants [4]. Generally terrigenous OM derived from terrestrial vegetation is more refractory and has a longer retention time in an estuary than planktonic OM [7]. However, in cases where terrigenous discharges are influenced by wastewater and other anthropogenic sources, OM tends to be more labile and enriched in increasing bacterial population associated with high organic loading [8].

Characterization of the source inputs, chemical nature, and OM reactivity in estuaries has been achieved through application of different approaches involving biological markers. For example, considerable attention has been focused on the utilization of stable isotopes as a tool for inferring their sources and following pathways of OM cycling in aquatic systems [9-13]. The stable isotope (C,N) signals have been coupled with organic $\mathrm{C} / \mathrm{N}$ elemental ratios to provide additional resolution and understanding of ongoing biogeochemical processes. The use of these tracers relies on the existence of gross differences between respective OM pools and the general enrichment of marine derived organic material in ${ }^{13} \mathrm{C},{ }^{15} \mathrm{~N}$ and elemental nitrogen relative to terrigenous OM $[10,14]$. The use of this approach is based on the assumptions that OM isotopic and $\mathrm{C} / \mathrm{N}$ ratios are conservative, and that their distributions in natural systems reflect only physical mixing of material from compositionally distinct end-member sources. However, isotope-based source assignments for OM are frequently confounded by potential modification of end-member signatures by biogeochemical processes, which are known to alter the isotopic and elemental composition of OM pools in estuaries $[5,10,15]$. 
Fatty acids also can be used reliably to distinguish OM sources within complex aquatic ecosystems. Because of their biological specificity, these fatty acids have been used to trace the origin and trajectory of $\mathrm{OM}$ in the ecosystems by distinguishing: autochthonous primary producers (e.g., dinoflagellates, diatoms); OM of primary (e.g., algal) and secondary (e.g., zooplankton, bacteria) trophic levels, and relative importance of terrigenous sources along the estuarine continuum $[10,16,17]$. However, these biomarkers have limitations too. For example, some fatty acid markers may be metabolized and transformed once consumed by the animal, and only their relative rather than absolute amounts can be measured.

While both the above approaches (fatty acids and stable isotopes) have limitations, the combination of these techniques has significantly improved the source determination of $\mathrm{OM}$ in aquatic systems $[10,18]$. In this study, we used fatty acids and stable isotopes $\left({ }^{13} \mathrm{C}\right.$ and $\left.{ }^{15} \mathrm{~N}\right)$ to investigate the origin of particulate and sedimentary $\mathrm{OM}$, and its fate into the food web in a mangrove estuary. This information is then used to gain insights into the trophic position and feeding relationships of three most common and important species of teleost representing pelagic, bentho-pelagic, and benthic feeders in the Rufiji estuary in Tanzania. To the best of our knowledge, the study provides the first overview on characteristics of the OM pools, and their incorporation into the food webs within Rufiji estuary.

\section{Methods and materials}

\subsection{Study site}

The study sites are located in Rufiji estuary, $100 \mathrm{~km}$ south of Dar es Salaam city, in the Rufiji River delta (Fig. 1). This river has a catchment area of $177400 \mathrm{~km}^{2}$ and is over $640 \mathrm{~km}$ long [19]. About $30 \mathrm{~km}$ from the coast, the lower Rufiji River branches out into a series of channels forming an impressive delta, covering approximately $1,200 \mathrm{~km}^{2}$ with $530 \mathrm{~km}^{2}$ covered by mangrove forests [20]. The four northern tributaries presently carry the bulk of the discharge into Rufiji River. The southern part of the delta, which is sheltered, receives little freshwater, and the water in front of this part of the delta are clear and saline and feature seagrass meadows and scattered patch reefs. Tidal influence in the delta is considerable [21]. 
In the upstream part of Rufiji catchment area, some small towns are located. The downstream part is free of industries, but in the delta, various pesticides are used in mangrove sections that have partially been cleared for rice cultivation [22]. The estuary of the Rufiji delta is an integral part of the largely undisturbed saline swamps, tidal marshes, woodland and mangrove forests. It is by far the largest delta in eastern Africa, and contains the largest continuous block of mangrove forest on the eastern seaboard of the African continent.

The mangroves (Heritiera littoralis, Avicennia marina, and Rhizophora mucronata) provide the dominant habitat in the estuary, but tidal marshes, seagrass meadows, and mud flats are also present. Several omnivorous crustaceans of commercial importance spend part of their life cycle in mangroves feeding on the detritus, live benthic microalgae, occasional animal material and fine inorganic particles [22].

The present study was carried out in three locations (Muhoro - station 1, Msomenistation 2, and Kalale - station 3), representing the south, middle and northern parts of the Rufiji delta (Fig. 1). These locations were chosen because they are representative of the entire estuary, and include a variety of adjacent habitats (i.e., mangrove stands, mud flats, and seagrass meadows) with sufficient diversity and densities of consumer organisms.

\subsection{Sample collection}

All flora, fauna, sediment and water samples were collected from three locations at the Rufiji estuary in June and July 2014 as part of a reconnaissance survey. Enough material was collected for three replicates. The main primary producers, including mangrove leaf tissue ( $A$. marina, $H$. littoralis, and $R$. mucronata), and thalli of most abundant algae (Ulva sp. and Padina sp.) were collected from 3 stations. Seagrass blades (T. hemprichii), were only found in sufficient quantity at station 1 (Muhoro area). A range of animals, including polychaetes, gastropods (Terebralia sp.), clams (Crassostrea cucullata), crabs (Uca sp.), were collected from all three locations; and Panaeid shrimps (Panaeus monodon) were collected from Stations 1 and 3. The animals under investigation are the dominant species at respective stations, within the Rufiji delta (21). Ten to twenty individuals of gastropods, bivalves, crabs and shrimps were dissected to remove muscle tissues, used for preparing the dry tissue pool. Dissected tissues were frozen (-20 ${ }^{0} \mathrm{C}$ ) and stored for analysis. 
Teleost (Trichiurus lepturus and Arius thalassinus) were collected from Stations 2 and 3, while Hilsa kelee were collected from Stations 1 and 3, where they were found in sufficient quantity. Six individuals of each species of fish were randomly selected from the total catch of each sample, and were euthanized in an ice slurry; Muscle tissues (skin removed) were collected from both sides of each fish, for biochemical analyses within $24 \mathrm{~h}$ of sample collection. All the samples were kept frozen $\left(-20{ }^{0} \mathrm{C}\right)$ until analysis, conducted within three months of sample collection.

The sediment samples were obtained by scraping the top 1-2 $\mathrm{cm}$ off the surface sediment at each three locations. Four liters of water were collected from each sampling site, and were transported back to the laboratory, where they were filtered through pre-combusted $(4 \mathrm{~h}$ at $450^{\circ} \mathrm{C}$ ) glass fibre filters (Whatman $\mathrm{GF} / \mathrm{F}, 0.7 \mu \mathrm{m}$ ). Three filter papers were used for each replicate and were put into cold storage at $-20{ }^{\circ} \mathrm{C}$ until further extraction, that were conducted within three months of sampling.

\subsection{Laboratory analyses}

\subsubsection{Lipid extraction and analysis}

For lipid extraction, $10 \mathrm{~g}$ wet weight of flora, $5 \mathrm{~g}$ dry weight (dw) of sediments, $3 \mathrm{~g}$ dry weight (dw) of filtrates, and between 300 and $500 \mathrm{mg} \mathrm{dw}$ of animal tissues, including three replicates for each type of sample at each location were made, following the modified extraction protocol in marine particles and sediment samples [23-25]. Dry weight samples were obtained by freeze-drying and homogenization of samples in batches. Sample was extracted with a mixture of $\mathrm{CH}_{2} \mathrm{Cl}_{2}$ and $\mathrm{CH}_{3} \mathrm{OH}$ (9:1 v/v ratio) in an automated solvent extractor (Dionex ASE 300; 3 cycles at $1500 \mathrm{psi}$ and $100{ }^{\circ} \mathrm{C}$ ). Recovery standard (50 mg/l $n$-hexatriacontane $\left.-\mathrm{d}_{50}\right)$ was added prior to extraction. The extracts were reduced in volume on a Büchi Syncore SPE to ca. $0.5 \mathrm{ml}$, and later they were blown dried under a gentle stream of $\mathrm{N}_{2}$. The total lipid extract (TLE) was subsequently separated into two fractions using $6 \mathrm{ml}$ glass columns packed with $500 \mathrm{mg}$ of Supelco Superclean LC-NH2 [26]. The columns were eluted with $\mathrm{CHCl}_{3} /$ isopropanol (15 ml of 2:1 v/v, neutral fraction) and $2 \%$ acetic acid in diethyl ether $(15 \mathrm{ml}$; acid fraction). The acid fraction was derivatized with $1 \mathrm{ml}$ of bromotriflouride $\left(\mathrm{BF}_{3}\right)$ in methanol and heated $\left(100{ }^{\circ} \mathrm{C}\right.$ for 
2 hours) to convert the fatty acids into their corresponding fatty acid methyl esters (FAMEs); the samples were further extracted with $\mathrm{NaCl}$ and hexane, and separation was achieved by centrifugation (10 min at $3000 \mathrm{rpm}$ ). FAMEs were removed from the upper hexane phase. 10 ppm of an internal standard (deuterated eicosanoic acid methyl ester) was added to each sample before analysis. To ensure that contamination was not introduced during extraction and/ separation of lipid fractions, blanks were prepared following the same protocol.

The analysis of FAMEs was performed using an Agilent 6890N GC interfaced to an Agilent 5973 MSD mass spectrometer operating at $70 \mathrm{eV}$, and scanning from $\mathrm{m} / \mathrm{z} 40-600$ (at 2.62 scans/sec), and the run-time was $68.42 \mathrm{~min}$. The extracts were injected in splitless mode (10 $\mu \mathrm{l}$; inlet pressure of $10 \mathrm{psi}$ with a flow rate $54.3 \mathrm{ml} / \mathrm{min}$ ) and separated on a HP-5 MS capillary column (5\% diphenyl dimethyl polysiloxane; $30 \mathrm{~m}$ length $\times 0.25 \mathrm{~mm}$ i.d. $\times 0.25 \mu \mathrm{m}$ film thickness). The samples were run at constant flow $(1.3 \mathrm{ml} / \mathrm{min})$ with helium as carrier gas. The interface temperature was set at $300{ }^{\circ} \mathrm{C}$; the source temperature was set at $230{ }^{\circ} \mathrm{C}$ and the MS quadrupole was maintained at $150{ }^{\circ} \mathrm{C}$, respectively. The samples were injected at $35{ }^{\circ} \mathrm{C}$ and the oven was programmed to $130{ }^{\circ} \mathrm{C}$ at $20^{\circ} \mathrm{C} / \mathrm{min}$ and then to $320^{\circ} \mathrm{C}$ at $6{ }^{\circ} \mathrm{C} / \mathrm{min}$, where it was held isothermally for 15 mins. The FAMEs were identified by comparing their characteristic mass spectra, ion fragments (base peak and molecular ion), retention times, and elution order published in literature [27,28], NIST online library, and Archives of Mass Spectrometry (http:// lipidlibrary.aocs.org/ms/arch_xyz/index1.htm). Quantification was based on specific fragments targeted in the total ion chromatograms generated from the lipid extracts analyzed in full scanmode. Recovery of deuterated hexatriacontane added prior to extraction ranged from 80 to $90 \%$. Internal standard (deuterated eicosanoic acid methyl ester) was used for quantification based on their response factors. Detection limit in the different standards ranged from 0.1 to $1 \mathrm{ng} / \mathrm{g}$. Reproducibility of internal standards was in the range of $\pm 3.5-7 \%$ for different compounds.

Fatty acids were designated as $\mathrm{X}: \mathrm{Y} \omega \mathrm{Z}$, where $\mathrm{X}$ is the number of carbon atoms, $\mathrm{Y}$ is the number of double bonds and $\mathrm{Z}$ is the position of the last double bond from the terminal methyl group. The fatty acid biomarkers (specific fatty acids and ratios of fatty acids) of the major potential food sources found in the Rufiji estuary were identified by comparing with the published literature (Table 1).

\subsubsection{Stable isotope analysis}


For stable isotope analyses, two replicate from all samples (primary producers, animals, sediment and POM) were oven-dried for $24 \mathrm{~h}$ at $60{ }^{\circ} \mathrm{C}$ and finely crushed $(<200 \mu \mathrm{m})$. The filters (containing suspended $\mathrm{OM}$ ) and sediment were acidified by $\mathrm{HCl}$ fumes in order to remove carbonates prior to drying and grinding [29].

Analyses were carried out on a fully automated Thermo scientific 20/20 isotope analyzer. Samples were combusted and the resulting gases were separated by gas chromatography, and then analyzed by continuous flow-mass spectrometry. Data are reported in $\delta$ notation relative to V-PDB standard and atmospheric nitrogen for carbon and nitrogen, respectively where:

$$
\left.\delta \mathrm{X}=\left(R_{\text {sample }} / R_{\text {standard }}\right)-1\right) \times 1000
$$

where $\mathrm{X}={ }^{13} \mathrm{C}$ or ${ }^{15} \mathrm{~N}$, and $\mathrm{R}={ }^{13} \mathrm{C} /{ }^{12} \mathrm{C}$ or ${ }^{15} \mathrm{~N} /{ }^{14} \mathrm{~N}$. Data quality control throughout the analysis was ensured by running a reference standard after every 10 runs. Analytical precision was \pm $0.1 \%$ and $\pm 0.3 \%$ or for ${ }^{13} \mathrm{C}$ and ${ }^{15} \mathrm{~N}$, respectively.

\subsubsection{Data analysis}

Statistical analyses (ANOVA) were conducted with Statistica 6.0 software. All data were checked for and met the normality and homogeneity variance requirements for parametric analyses. Non- metric multidimensional scaling (NMDS) was also run using PRIMERv6 software to explore similarities and differences in the fatty acid profiles of fish, invertebrates and organic matter sources.

\section{Results}

\subsection{Fatty acids in primary producers}

Preliminary analyses for primary producers have indicated no significant differences between locations (ANOVA; $\mathrm{p}>0.05$ ). Therefore, their samples were combined for all three locations (stations 1, 2, 3). Palmetic acid (16:0) was the most abundant compound in the FA profiles of plant samples, except for LCFAs which were more abundant in mangrove leaves (Table 2). In the leaves of three mangroves species, LCFAs (long-chain fatty acids, with a carbon number greater than 24), indicator of vascular plants, contributed between 34.8 and $42.4 \%$ of the 
total fatty acids (Table 2). The contribution of PUFA (polyunsaturated fatty acids) 18:3 $\omega 3$, $18: 3 \omega 6$ to mangrove leaves ranged between 3.8 to $11.8 \%$ and 2.3 to $7.1 \%$, respectively. In

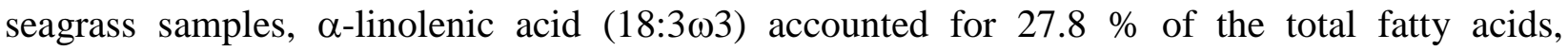

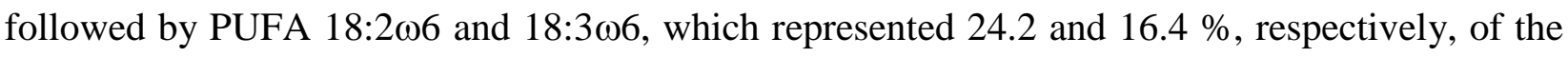
total fatty acids. The dominant fatty acids in green and brown macro algae, Ulva sp. and Padina

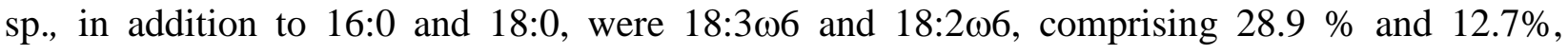
respectively, of the total fatty acids for Ulva sp; $11.2 \%$ and 3.8\% for Padina sp. (Table 2).

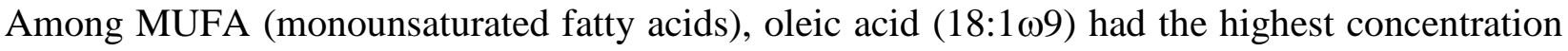
(22.6\% of the total) in brown algae, whereas in green macro algae they only represented $5.2 \%$ of the total fatty acids.

\subsection{Fatty acids in estuarine particulate (POM) and sedimentary organic matter (SOM)}

Fatty acid profiles of estuarine POM and SOM are given in Table 3. Ubiquitous 16:0 and 18:0 contributed 29.4, 34.7, and 36.8\% of total fatty acids in POM for stations 1-3, respectively, and about 28.5, 39.7 and $34.2 \%$ of the total fatty acids in SOM for stations 1-3, respectively.

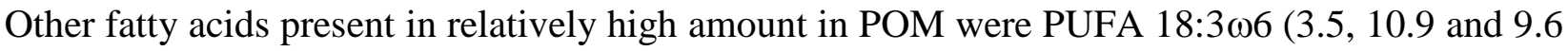
$\%$ for stations $1-3$, respectively), $18: 2 \omega 6(1.7,10.1$, and $14.7 \%$ total fatty acids for stations $1-3$,

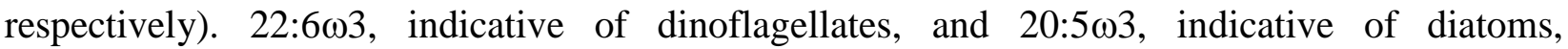
significantly contributed (19.3\% and 4.6, respectively) to the total POM fatty acids for station 1 . The contribution of the odd-branched fatty acids (15:0 and 17:0, iso and anteiso) and the cis-

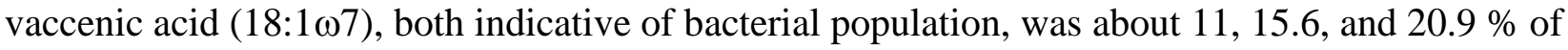
total fatty acids in POM from stations 1-3, respectively, and 23.9, 38.8, and $26.9 \%$ of total fatty acids in sediments from stations 1-3, respectively (Table 3). The LCFAs, indicators of terrestrial inputs, were detected in both POM and surface sediment of each station, but then maximum contribution occurred in surface sediments at stations 2-3 (8.5 and 11\% of total fatty acids, respectively). Results from one-way ANOVA for fatty acid biomarkers for major food sources across locations indicate that there is a significant difference $(\mathrm{p}<0.05)$ in diatoms biomarkers which appeared to be more abundant in sediment samples at station 1 compared to stations 2 and 3. Dinoflagellates and brown algal derived biomarkers were significantly high in POM samples at station 1 compared to stations 2 and 3 . 


\subsection{Fatty acids in animal samples}

The fatty acids corresponding to potential food sources identified in various animal tissues are presented in Table 4. Independent of the location, ubiquitous fatty acid (16:0 and 18:0) contribution was relatively high, accounting for $20.4-23.7 \%$ of the total fatty acids in the muscle tissues of polychaeta. The relative contribution of other predominant polyunsaturated fatty acids,

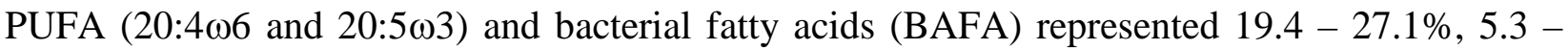
$14.2 \%$ and 15.1 - 29.6\%, of the total fatty acids in polychaeta, respectively. Diatoms markers (20:5 13$)$ contribution to the tissue of Polychaeta was significantly higher $(\mathrm{p}<0.05)$ in station 1 than in stations 2 and 3 (Table 4). The most abundant fatty acids in the tissues of Terebralia sp. was saturated fatty acids (SAFAs) (16:0 and 18:0) and BAFAs accounting for $22.1-29 \%$ and $31.3-41.0 \%$, respectively, of the total fatty acids. Terrestrial inputs of long-chain fatty acids (LCFAs) accounted for 8.9 and $12 \%$ of the total fatty acids in these gastropods. In addition to ubiquitous fatty acid varieties (16:0 and 18:0), the filter feeders (C. cucullata), had highest

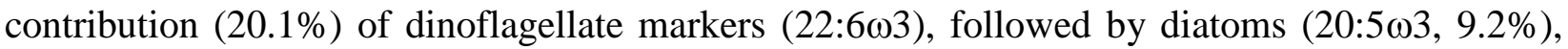

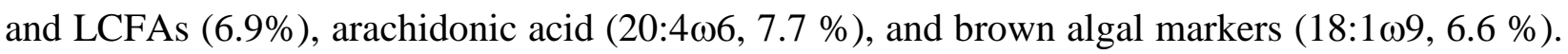
For crabs (Uca sp.), SAFA (16:0 and 18:0) contributed between 32.3 to $39.9 \%$ of total fatty acids, followed by LCFAs (14.9 - $19.5 \%$ ), and BAFAs (18.5 - 18.9\%) at stations 2 and 3. Diatoms marker contributed significantly ( $<<0.05,15.5 \%$ ) to the muscle tissues of Uca sp. at station 1 (Table 4). The fatty acid profiles of Panaeid shrimp (P. monodon) contained high amounts of SAFAs (16:0 and 18:0) (22 - 23.7\%), BAFAs (11.9 - 27.2\%) and terrestrial (LCFAs) inputs (11 -

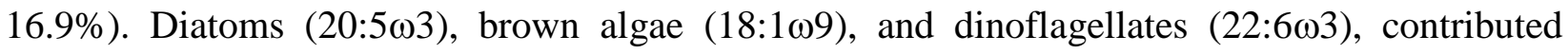
significantly ( $\mathrm{p}<0.05,15.7,12.2$, and $4.5 \%$, respectively) to the tissues of shrimps collected from station 1.

Fatty acid compositions in teleost (H. kelee, T. lepturus and A. thalassinus) are presented in supplementary data, Table S1, and the major contributing fatty acids markers are given in figure 2. The analysis of teleost samples revealed the presence of biomarkers from variety of food sources, indicative of their higher trophic level. Regardless of the species and locations, SAFA (16:0 and 18:0) contributions were the highest (29.2 - 32.3\%, of the total fatty acids). The pelagic feeders, $H$. kelee, contained relatively high amounts of brown algae $(18: 1 \omega 9,15.6 \%)$ at station 1 , 


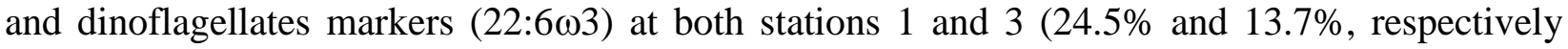
(Fig. 2). The LCFA inputs were relatively low (2.4 - 6.7\%). For bentho-pelagic and benthic feeders fish, T. lepturus and A. thalassinus, the contribution of BAFAs, diatoms (20:5 $\omega 3$ ), and LCFAs were the highest (17.5 - 24.0\%, $11.4-14.1 \%$, and $9.9-13.6 \%$, respectively), followed

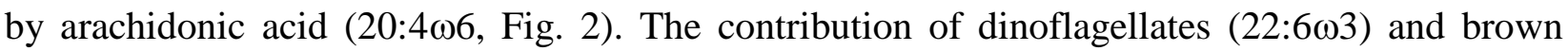
algae (18:1 $\omega 9)$ was very low (Fig. 2).

A two-way ANOVA on food-derived biomarker input among animals and between stations revealed significant differences among species ( $p<0.05$ ), but not between the stations ( $p$

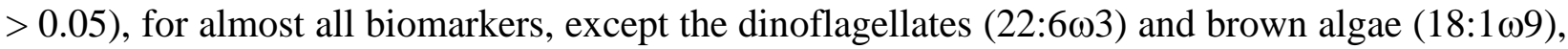
which significantly contributed to the tissues of $H$. kelee in station 1 than in station 3 . Additionally, the non- metric multidimensional scaling (NMDS) plot (Fig. 3) indicated that three fish species in station 2 and 3 were trophically connected with crabs (Uca sp.), polichaetes, penaeid shrimps as they were likely to feed on/linked with sediment (SOM) and particulate (POM) organic matter. H. kelee in station 1 presented a FA profile close to POM and green algae (Uva sp.) and it seemed that this population was different from the population collected in station 2 and 3 (distance in between). Furthermore, crabs (Uca sp.) was possibly the important group that connected T. lepturus and A. thalassinus to the primary producers.

\subsection{Stable isotope composition}

Stable isotopes $\left(\delta^{13} \mathrm{C}\right.$ and $\left.\delta^{15} \mathrm{~N}\right)$ data for primary producers, consumers, estuarine POM, and sediments are presented in Table 5. Distinctive groupings and separations of various sources of organic matter across different trophic level provided by $\delta^{13} \mathrm{C}$ and $\delta^{15} \mathrm{~N}$ are shown in Figure 4 . The $\delta^{13} \mathrm{C}$ values for primary producers ranged from -28.5\% for mangrove leaves to $-13.01 \%$ green macro algae thalli, while those for $\delta^{15} \mathrm{~N}$ ranged from 5.6\% (mangrove leaves) to 7.63\% (brown algae thalli). The estuarine POM and sediment distribution of $\delta^{13} \mathrm{C}$ and $\delta^{15} \mathrm{~N}$ ranged from 27.7 to $29.6 \%$ and 2.77 to $7.0 \%$, respectively. $\delta^{13} \mathrm{C}$ and $\delta^{15} \mathrm{~N}$ values of consumers (5 species of macrozoobenthic and 3 species of teleost) also varied greatly; $\delta^{13} \mathrm{C}$ ranged from $-21.8 \%$ (polychaetes) to $-13.9 \%$ (A. thalassinus), and for $\delta^{15} \mathrm{~N}$ from $9.5 \%$ (polychaetes) to $16.43 \%$ ( $\mathrm{A}$. thalassinus), indicating a general enrichment with increasing trophic level (Fig. 4, Table 5). The 
baseline value for $\delta^{15} \mathrm{~N}$, which was derived from the mean $\delta^{15} \mathrm{~N}$ values of primary producers (mangrove leaves, seagrass blades, and brown and green algae thalli) was 6.5. Taking into account a trophic fraction of 3.4 \% per trophic level (Vander Zanden and Rasmussen 2001), the food web spanned ca. 3 trophic levels between primary producers and fish species (Fig. 5). Except for the shrimp (P. monodon ), which occupied the same trophic level (3-4) as the predatory fish species, other invertebrates were generally located between trophic level 1 and 3 (Fig. 5).

\section{Discussion}

\subsection{Fatty acids in primary producers.}

The FA profiles of major primary producers in the Rufiji estuary confirmed that specific biomarkers could be traced with confidence to the higher trophic levels. Consistent with this, LCFAs were found in high concentrations in mangrove leaves as reported by other researchers [30-32]. These saturated FAs were not found in significant quantity in other major food sources of primary producers (e.g., seagrass and macroalgae), thus providing a good tracer for mangrove

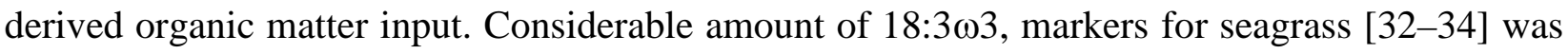
found in the samples of seagrass blades cleaned of epiphytes. Although this FA was found in mangrove leaves and thalli of brown macroalgae, it occurred in much lower concentrations. Thus, seagrass biomarkers results are analyzed carefully to apportion source inputs, taking this fact into consideration. Green macroalgae (Ulva sp.) was the most abundant algal species in stations 2 and

3 , contributing to the OM input for organisms in the estuary. Samples of Ulva sp. contained high

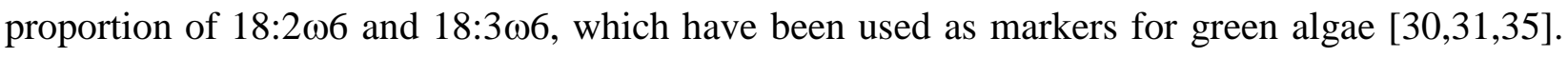
Contrary to previous reports $[30,31]$ these FAs were also found in considerable amount in seagrass blades. Brown algae (Padina sp.) contained high proportion of oleic acid (18:1 $\omega 9$ ), which has been reported as a diagnostic biomarker for brown algae [32,36]. Although this fatty acid was also found in other primary producers, its proportions was much low, confirming the reliability of this biomarker as a diagnostic source indicator in this study.

\subsection{Fatty acids in surface water and sediment}


POM and sediment samples collected from three stations contained a wide range of fatty acids, indicating the contribution from a variety of OM sources. Station 1, which was statistically different from stations 2 and 3 in terms of dinoflagellates contributions to POM and diatoms to sediments, indicated that OM was predominantly derived from a mixture of autochthonous sources, including fresh and detrital phytoplankton, zooplankton and bacteria. This was supported by high concentrations of compounds indicative of a mixed plankton community such as 14:0, 16:0, 16:1 $\omega 7$, and PUFA $\mathrm{C}_{18}, \mathrm{C}_{20}$, and $\mathrm{C}_{22}$ fatty acids. The abundance of these more ubiquitous compounds, in addition to other compounds specific to phytoplankton, indicated that OM in lower reaches of the Rufiji estuary (station 1) was mostly composed of a planktonic/microbial

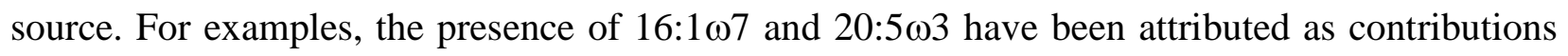
of diatoms $[37,38]$. These fatty acids contributed 10.2 and $15.1 \%$ of total fatty acids in POM and sediment, respectively, in station 1 . In addition, 22:6 103 , commonly attributed to dinoflagellate sources of phytoplankton [37,39] were also present in significant amount in POM samples from station 1. LCFAs, derived predominantly from vascular plant sources (terrestrial inputs) were present in station 1. However, the reduced contribution of these fatty acids in both POM and sediment samples from station 1 indicate that, quantitatively, the mangrove biomass and terrigenous inputs were not a significant contributor to the OM pool within this part of the estuary. The small contribution of OM derived from terrigenous sources was not surprising given the fact that the southern part of the Rufiji estuary, where station 1 is located, is sheltered and receives little freshwater [40], thereby reducing the export of mangrove-derived detritus and terrestrial inputs to the adjacent habitats.

Due to the shift in the drainage pattern of the Rufiji River in the 1970s [40], Stations 2 and 3 , in the middle and north, of the estuarine delta, receive enhanced freshwater outflow (40).

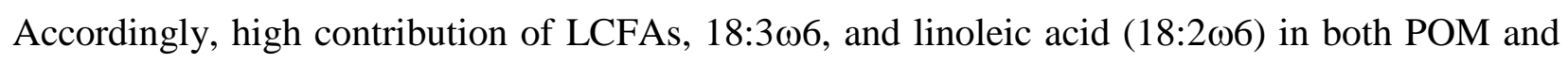
sediment samples from stations 2 and 3 was expected. High concentrations of LCFAs particularly to the surface sediments in stations 2 and 3 suggested contribution of nearby mangrove biomass and terrestrial sources, perhaps due to the surrounding land use activities, such as rice cultivation, fishing, and the harvest of firewood, charcoal, and mangroves poles [21]. LCFAs contribution to these sites was comparable to those measured elsewhere in tidal flats receiving OM derived from mangrove forest/terrestrial plants [30,31,41,42] The high concentration of the PUFA $(18: 3 \omega 6)$ 
recorded at these stations indicated the contribution of Ulva sp. to the OM pool. The other most

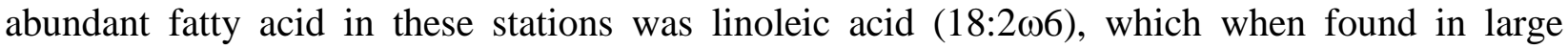
proportions is attributed to agricultural products [43]. Although, this fatty acid was particularly

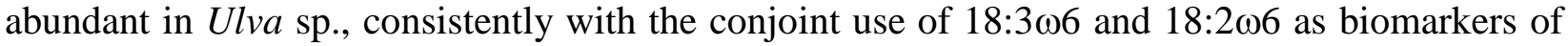
green macroalgae [30], which could mean high contribution of Ulva sp., to the OM pool, its relatively small contribution to OM pool at station 1 indicate that its input at stations 2 and 3 was most likely from the surrounding rice fields. Consistent with this, linoleic acid constituted > 38\% of total FAs in rice [44]. Moreover, the green macroalgae has been described as a good indicator of nitrogen enrichment in an estuarine environment [45]. Although nutrients have not been measured in this study, the proliferation of green algae observed in these parts of the estuary is perhaps due to excess nitrogen, which is delivered to the estuary from agricultural activities in the catchment. Notably, fertilizers are intensively used in the rice fields around Rufiji delta.

Because they are usually synthesized by bacteria, the odd branched FAs and 18:1 $\omega 7$ have been used as markers for the presence of microorganisms in the environment $[30,46]$. In the Rufiji estuary, the contribution of these FAs in POM was small (generally $<10 \%$ ) of the total FAs concentration and this was most likely due to resuspension of bacterial communities associated with organic detritus on surface sediment [47]. However, in surface sediments, particularly in stations 2 and 3, these FAs constitute a significant fraction (23.9 to 31.8\%) of the total FAs. This large quantity of bacterial derived FAs implied a rich microbial community on surface sediments.

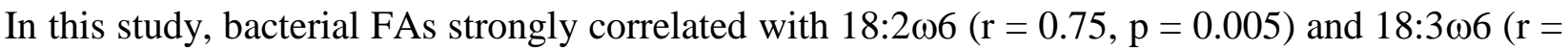
0.96, $\mathrm{p}=0.001)$, markers of green algae. Assuming that the linoleic acid indicates agricultural inputs at stations 2 and 3, which might also supply enough nutrients for algal growth, the large presence of bacteria at these stations was most likely a response to a substantial input of organic matter from the surrounding watershed. Bacterial populations have been reported to respond positively to the increase of OM input which is used for metabolic activities [46,48].

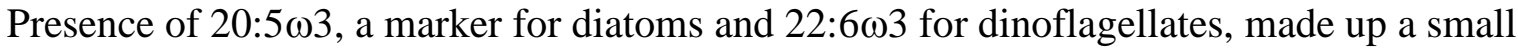
fraction (generally $<3 \%$ ) of the total FAs pool associated with POM at stations 2 and 3 . The presence of these compounds was most likely due to growth of these organisms in the water column. 22:6 $\omega 3$ was very negligible $(<0.5 \%)$ in the sediments samples at station 2 , and not detected in station 3, which agreed with the more pelagic nature of dinoflagellates, and the low 
concentration of this biomarker found in water samples. It is likely that dead dinoflagellate cells that sink to the bottom are quickly decomposed, and their biomarker signature is permanently lost from the sediment record.

\subsection{Chemical proxies and dietary intake}

The fatty acid composition of consumers and predators is helpful to evaluate the relative importance of various OM sources in their diets $[32,35,49]$. The FA profiles of polychaetes were dominated by bacterial markers (BAFAs), EPA (20:5

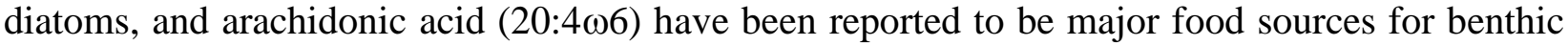
organisms such as annelids and mollusks [50-52]. LCFAs were more abundant in polychaete tissues in stations 2 and 3 than in station 1 . This could be associated with the availability and abundance of these FA in the sediments of stations 2 and 3 than in station 1. The main food source for the gastropod (Terebralia sp.) was bacteria, macroalgae and mangroves, judging by the relative contribution of their respective markers. The dominance of BAFAs and macroalgae sources in the diet of these organisms has also been reported in other sub-tropical estuaries [30,31]. However, contrary to Meziane and Tsuchiya [31], LCFAs - indicative of mangrovederived OM - contributed substantially to the diet of gastropods in this study. It was not clear whether the LCFA contribution to gastropods was related to the availability of mangrove-derived $\mathrm{OM}$ in areas where gastropods were collected or preference of this food source by gastropods. Slim et al. [53] highlighted the dominant role of the snail Terebralia palustris in removing leaf litter in the Gazi Bay mangrove forest. On the other hand, the work of Tenore [54,55] documented the role of the detritus derived from vascular plants in supporting the bacterial biomass for deposit-feeders. Since Terebralia sp. collected from Rufiji estuary had high contribution of bacterial FAs, it is likely that mangrove-derived OM was ingested to assimilate the attached bacteria which are rich in nitrogen.

The filter feeding species studied (C. cucullata), had a high dinoflagellate (22:6ஸ3)

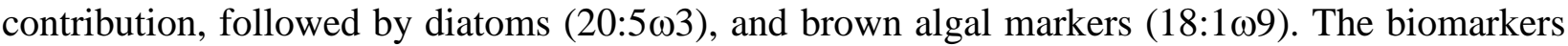
for dinoflagellates and diatoms have been reported to be major food sources for filter feeders, and essential for their growth and survival $[38,41,56]$. In this study, the higher contribution of dinoflagellates compared to diatoms - as shown by eicosapentaenoic acid/docosahexaenoic acid 
(EPA/DHA) ratio of $<1$ - is likely to be related to the fact that dinoflagellates tend to be pelagic organisms, directly available to filter feeding bivalves from the water column. On the other hand, benthic diatoms which were mostly found on surface sediments must have been suspended into the water column to become available to filter feeding bivalves. Mangrove-derived LCFAs also contributed to the tissues of filter feeding bivalves in more or less abundance as FAs derived from diatoms and brown algae, suggesting that mangrove-derived OM was also consumed by bivalves. Alfaro et al. [32] found that mangrove-derived OM contributed to the diet of bivalves, at least when found in proximal areas. However, the bivalves collected in this study are on the tidal flat, ca $4 \mathrm{~km}$ away from mangrove forests near station 1. Previous studies have challenged the hypothesis that mangroves provide a major source of nutrients to primary consumers [31,57-59] According to Meziane and Tsuchiya [31], the export of mangrove-derived organic matter was restricted to the nearest part of the intertidal flat; and bacterial, diatom and green macroalgae were the main food source of primary consumers in the area. In the present study, the presence of significant amounts of LCFAs in surface sediments, POM and in the muscle samples of consumers such as bivalves suggest that OM derived from mangrove forests were exported to the intertidal flat and contributed to the food source in primary consumers, supporting the hypothesis that mangroves contribute enough source of nutrients to consumers.

Bacteria and mangrove/terrestrial plants are the main food sources of crabs (Uca sp.), according to the relative contribution of BAFAs and LCFAs in the samples. Crabs are among few organisms able to directly ingest mangrove leaves accelerating the degradation time of mangrove litter and enhancing nutrient availability to microbial communities [60,61]. Thus crabs represent also a key crucial link between basal organic matter sources and high trophic level consumers. This result concurs with data reported from other estuaries [30,31,62]. The preference for BAFAs has been reported in an experimental study, which described high assimilation efficiency (about 98\%) of microheterotrophs by Uca vocans [63]. Diatoms (20:5 contributed significantly to the diet of crabs at station 1 only. These FAs also significantly contributed to surface sediments and POM at this station; their utilization by crabs is most likely connected to the increase in the biomass of diatoms and brown algae within this area. Thus, their availability may certainly induce a better use of these microorganisms by primary consumers. Ingestion of algae has also been reported for other populations of Uca vocans [30,31,63]. According to Kharlemenko et al. [35], presence of dinoflagellates (22:6 $\omega 3)$ marker in the tissues 
of macrozoobenthic species may reflect a carnivorous diet. However, very low contribution of

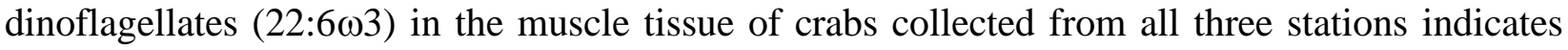
that meiofauna contributed meagerly to the diet of these crab species.

Panaeid shrimps are known to feed extensively on various kinds of food sources including microheterotrophic protozoans, meiofauna, detritus, benthic diatoms and algae [32,64-66]. In this study, the fatty acid profile of shrimp ( $P$. monodon) showed a wide range of organic compounds, among which BAFAs, diatoms (20:5 $\omega 3$ ), LCFAs were dominant at both stations. The

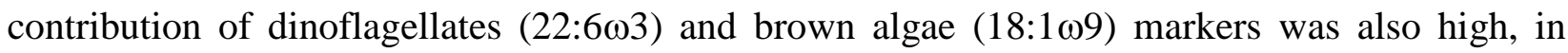
shrimps collected from station 1, reflecting the filter feeding behavior of these invertebrates $[32,56,67,68]$.

PUFAs dominated the FA composition in all fish species (Fig. 2). The most common biomarkers found within $H$. kelee individuals were dinoflagellates (22:6ஸ3), brown algae (18:1 $\omega 9)$, which were readily available in the water column for direct consumption, or indirectly through filter-feeding preys which these fish consume. Diatom markers (20:5 $\omega 3)$ were also present, but in a relatively small quantity compared to dinoflagellates. The ratios between EPA and DHA, which could be used as a trophic marker for the feeding mode of estuarine fish (52), were higher $(2.7$ - 3.9) in $H$. kelee compared to other fish species. The high DHA: EPA ratio indicated the pelagic feeding mode of these species, which was consistent with previous studies reporting the importance of both pelagic flora and fauna in the diet of these fishes [68,69]. The contribution from bacterial markers (BAFAs) and LCFAs were high only in $H$. kelee collected from station 3, reflecting the opportunistic feeding habit on the most available food sources by this species.

The main food sources for $T$. lepturus and $A$. thalassinus, regardless of the location, were BAFAs, diatoms (20:5 13 ), and mangrove/terrestrial-derived inputs (LCFAs). The LCFAs and BAFAs were also present in high concentration in surface sediments collected from stations 2 and 3. Hence, their dominance in the diet of these species reflects the food preference related to OM

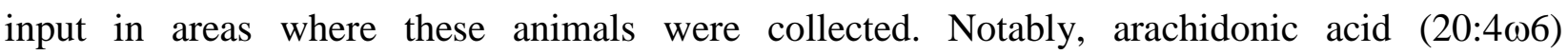
contribution was also high for these species, indicating a food chain based on available benthic food sources [50,51]. Benthic organisms such as annelids, molluscs and crabs showed an elevated

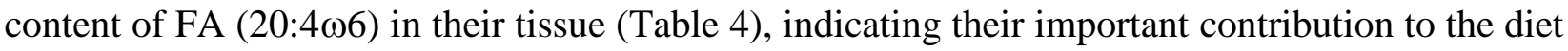
of these fish. The DHA:EPA ratio in T. lepturus and A. thalassinus was very low (0.12 to 0.23 , 
and 0.02 to 0.08 , respectively) compared to those in $H$. kelee. These two fatty acids are integral parts of cell membranes, and are therefore, retained in the tissues of each organism. This fact makes it more difficult to use DHA and EPA as trophic markers, since each organism incorporate these PUFAs into their membranes and not solely use them for nutritional purposes [70,71]. Thus, the contents of these fatty acids can vary from one species to another depending on their physiology and metabolism. However, the decreasing DHA:EPA ratio from pelagic ( $H$. kelee) to benthic (A. thalassinus) feeding fish is a trend that was also observed in the DHA:EPA ratio in invertebrates. Although the pelagic fauna has not been investigated in this study, previous study by Ulimboka and Shilla (2013, unpublished data) on pelagic fauna (calanoids and cyclopoid copepods, and fish larvae) collected from the same locations as in this study, indicated high DHA:EPA ratios (3.3 to 4.1) compared to the benthic fauna sampled (0.0 to 0.3). The high DHA:EPA ratio (2.2) for invertebrates in this study was only recorded for filter-feeding bivalves (C. cucullata), which reflected its pelagic feeding mode. Based on these facts it is likely that not only the physiology of fish, with regard to maintaining membrane fluidity, but also the dietary composition influenced the DHA:EPA ratio in respective fish species. Thus, the DHA:EPA ratio could be used as a trophic marker for tracing the feeding characteristics in these fishes. However, this particular trend needs to be further tested by incorporating a wide spatial and temporal coverage for both fish species and their prey in future studies.

Since isotope compositions of muscle tissue reflect animal feeding history [72], the stable isotope ratios of these primary consumers further provide useful information regarding to their food sources and diet. In the present study, the $\delta^{13} \mathrm{C}$ and $\delta^{15} \mathrm{~N}$ signatures for all primary producers cluster away from all consumers studied, although values are within range of other previous studies $[32,48,73]$. Consumers such as polychaetes worms, bivalves, crabs appeared between mangrove leaves and algae, although slightly closer to mangrove leaves (Fig. 3). The isotopic variation between primary producers and consumers may be the result of long-term dietary differences among individual species, and the fact that the consumers probably feed on two or more food sources within their surroundings. Further studies, incorporating a wider temporal range, may need to be conducted to clearly identify the long-term dietary differences. As expected, the $\delta^{13} \mathrm{C}$ and $\delta^{15} \mathrm{~N}$ signatures of shrimps and fish species confirm the wide variety of carbon sources and correctly place these invertebrates within the higher trophic levels of the local food web. 
Unlike FAs profile which revealed significant differences $(\mathrm{p}<0.05)$ on food-derived biomarkers input among animals and between stations, the isotopic values for primary producers and consumers did not differ significantly among sites $(\mathrm{p}>0.05)$. Based on this, the analysis of presumed food sources in this study relied much on the FAs profile as discussed above; and isotopic variation, particularly those of $\delta^{15} \mathrm{~N}$, were used to describe the trophic structure and estuarine food web as discussed in the following subsection.

\subsection{Trophic structure and estuarine food webs}

The $\delta^{15} \mathrm{~N}$ values of fish within Rufiji estuary do not vary greatly among these species of differing feeding modes. Assuming a fractionation of 3.4\%o per trophic level $[74,75]$, the $\delta^{15} \mathrm{~N}$ of each fish collected in the Rufiji estuary spanned ca 1.1 trophic levels, with all values lying within the range of one trophic level. Therefore, all studied fish species occupied a similar trophic level in the Rufiji estuary. The $\delta^{15} \mathrm{~N}$ values for fish in this study ranged from 11.7 to $16.4 \%$, which is slightly higher than those recorded for closely related species in other tropical estuary [76,77]. These differences in $\delta^{15} \mathrm{~N}$ values are likely to reflect a difference in the source values of $\delta^{15} \mathrm{~N}$ within different estuaries and habitats. Previous studies have shown that nitrate-enriched wastewater input into estuaries causes enriched $\delta^{15} \mathrm{~N}$ values in estuarine plants [78,79]. The catchment in the Rufiji estuary is used for agriculture, mainly rice cultivation and nutrient loading from cleared areas under cultivation is relatively high [22]. These nutrient sources could cause shifts in the stable isotopic composition of primary producers and consumers in the food web [79].

Both fatty acid and stable isotope results revealed that the food web in Rufiji estuary depended on a variety of carbon sources, contributing to different degrees, to the diets of primary consumers. The major primary producers (mangroves, macroalgae, seagrass and phytoplankton) are all potential food sources to the three abundant members of the near-shore fish species as shown by fatty acid profiles and stable isotope values. The non- metric multidimensional scaling (NMDS) plot (Fig. 3), as described in results subsection 3.3, further provide an evidence that variety of potential food sources support the food web in Rufiji estuary. Terrestrial/mangrovederived material appeared to be more important at stations 2 and 3, which receive large amount of 
freshwater inflow. Unlike in other studies [31,32,59-61], mangrove-derived material seemed to contribute to the food of primary consumers in adjacent habitats (mud flats). This suggests that terrestrial OM is exported further into the open coastal waters in Rufiji estuary. Furthermore, the contribution of mangrove litter to the microbial food web appeared to be important to a variety of primary consumers, which are then consumed by secondary consumers and predators higher up the food chain.

As expected, the brown algae and phytoplankton (benthic diatoms and dinoflagellates) contributed significantly to the estuarine food web at station 1. In contrast, seagrass although it was abundant at this site, contributed minimally to the food source. Terrestrial/mangrove derived sources were present at this station, but their contribution to the food web was less important than autochthonous (estuarine and marine related OM). The small contribution of OM derived from terrestrial sources could be related to freshwater flow, the primary mechanism for delivery of terrestrial OM, which is usually very little in this part of the estuary compared to other stations (Fig. 1, [40]. While this study did not look at the seasonal variations in carbon and nutrient sources, it is likely that the importance of these carbon sources may differ. For example, during wet seasons, increased rainfall and river flow could potentially increase the delivery of terrigenous carbon sources, making them available to the food web. Further research on abundance and transport of various sources of nutrients throughout the estuary, and over different seasons, which may provide further insight on the food web dynamics of this economically and ecologically important estuary, is of paramount importance.

\section{Synthesis and concluding remarks}

$\delta^{15} \mathrm{~N}$ and $\delta^{13} \mathrm{C}$ isotopes provided a generally good distinction between trophic levels and carbons sources. However, the addition of fatty acid profile analyses proved to be a powerful and sensitive in describing the origin and pathways of material transfer between primary producers and abundant members of the fish fauna in Rufiji estuary. Based on fatty acids results obtained from this study, it appears that the food web at Rufiji estuary depends on a variety of carbon sources. The major primary producers (mangroves, macroalgae, seagrass and phytoplankton) all contributed, to a different degrees, to the diets of primary consumers. The prevalence of different organic matter supporting the food web is an indication of presence of stable structures of 
estuarine food webs. This is because there are various trophic resources base in the food webs. On this lieu, the multiple trophic connectivity of consumers at higher trophic levels to the primary producers is viable. However, through anthropogenic disturbances such as pollution and high rate of removal (via fishing) of species like A. thalassinus that demonstrated high omnivore index and trophically connected directly to the primary producers and consumers at different trophic levels, can threaten the estuarine food web structure and ultimately the ecosystem health. This knowledge is of crucial importance in our understanding of the ecological balance and potential responses of these ecosystems to human impacts.

Like many estuaries throughout the world. Rufiji estuary is characterized by both high species diversity and habitat complexity. However, specific comparison with other estuaries, for example, Matapouri estuary, New Zealand [32], Okukubi estuary, Japan [31], and Bahamas Islands [59], shows that mangrove-derived materials in the Rufiji estuary have much wider effect on the food web since much of its organic matter appear to be exported to the adjacent habitats and contribute to the diet of primary consumers. Ongoing research on the transport of various sources of nutrients throughout the estuary, and over different seasons, may provide further insight on the processes/factors which modulate the spatial and temporal variability of food sources in this rich and diverse tropical estuarine system.

\section{Acknowledgments}

Dativa Shilla is grateful to the Swedish Institute (SI), which provided financial support for this work during her post-doctoral training. The following persons are kindly thanked for their help in this research: Mr. Richard Masinde and Amos Lugata, for sampling and initial processing of samples (Tanzania), Dr. Daniel Shilla for organizing all the sampling campaign logistics, Susanne Carlson and Lena Lundman for valuable practical assistance.

\section{Reference}

1. Amon RMW, Benner R. Photochemical and microbial consumption of dissolved organic carbon and dissolved oxygen in the Amazon River system. Geochim Cosmochim Acta. 1996;60:1783-1792.

2. Raymond P, Bauer J. DOC cycling in a temperate estuary: a mass balance approach using 
natural 14C and 13C isotopes. Limnol Oceanogr. 2001;46:655-667.

3. Jassbyl AD, Cloern JE, Thomas M. Organic carbon sources and sinks in San Francisco Bay: variability induced by river flow. Mar Ecol Prog Ser. 1993;95:39-54.

4. Canuel EA, Zimmerman AR. Composition of particulate organic matter in the southern Chesapeake Bay: sources and reactivity. Estuaries. 1999;22(4):980-994.

5. Ranjan RK, Routh J, Ramanathan AL, et al. Elemental and stable isotope records of organic matter input and its fate in the Pichavaram mangrove-estuarine sediment (Tamil Nau, India). Mar Chem. 2011;126:163-72.

6. Ranjan RK, Routh J, Clump JV, et al. Sediment biomarker profiles trace organic matter input in the Pichavaram mangrove complex, southeastern India. Mar Chem. 2015;171:4457.

7. Macko SA, Engel MH, Parker PL. Early diagenesis of organic matter in sediment: assessment of mechanisms and preservation by the use of isotopic molecular approaches. In: Engel MH, Macko S, editors. Organic geochemistry, principles and applications. New York and London: Plenum Press; 1993. p. 211-224.

8. Maksymowska D, Richard P, Piekarek-Jankowska H, Riera P. Chemical and isotopic composition of the organic matter sources in the Gulf of Gdansk (Southern Baltic Sea). Estuar Coast Shelf Sci. 2000;51:585-598.

9. Thornnton SF, McManus J. Application of organic carbon and nitrogen stable isotope and $\mathrm{C} / \mathrm{N}$ ratios as source indicators of organic matter provenance in estuarine systems:evidence from the Tay estuary, Scotland. Estuar Coast Shelf Sci. 1994;38:219-33.

10. Canuel EA, Cloern JE, Guckert JB, et al. Molecular and isotopic tracers used to examine sources of organic matter and its incorporation into the food webs of San Francisco Bay. Limnol Oceanogr. 1995;40:67-81.

11. Dalsgaard J, St. John M, Kattner G, et al. Fatty acid trophic markers in the pelagic marine environment. Adv Mar Biol. 2003;46:225-340.

12. Iverson SJ, Field C, Bowen DW, et al. Quantitative fatty acid signature analysis: a new method of estimating predator diets. Ecol Monogr. 2004;74:211-235.

13. Kelly JR, Scheibling RE. Fatty acids as dietary traces in benthic food webs. Mar Ecol Prog Ser. 2012;446:1-22.

14. Guest MA, Nichols PD, Frusher SD, et al. Multi-scale spatial variation in stable isotope and fatty acid profiles amongst temperate reef species: implications for design and interpretation of trophic studies. Mar Ecol Prog Ser. 2010;410:25-41.

15. Cloern JE, Canuel EA, Harris D. Stable carbon and nitrogen isotope composition of aquatic and terrestrial plants of the San Francisco Bay estuarine system. Limnol Oceanogr. 2002;47:713-729.

16. Quemeneur M, Marty Y. Sewage influence in a macrotidal estuary, the Loire, France. Estuar Coast Shelf Sci. 1992;34:347-63. 
17. Budge SM, Parish CC, Mckenzie C. Fatty acid composition of phytoplankton, settling particulate matter and sediments at a sheltered bivalve aquaculture site. Mar Chem. 2001;76:285-302.

18. Countway RE, Canuel EA, Dickhut RM. Sources of particulate organic matter in surface waters of the York River, VA estuary. Org Geochemistry 38 365-379. 2007;8:365-379.

19. UNEP. Eastern africa atlas of coastal resources: Tanzania. Nairobi; 2001.

20. Sørensen C. Fisher, farmer, forester: smallholder management in the Rufiji Delta of Tanzania. A field report presented to the Danish Council for development research. 1998.

21. REMP. A report on biodiversity of Rufiji District - A summary Rufiji environmental management project technical report No. 44. 2003.

22. Taylor M, Green E, Ravilious C. Mangroves of East Africa. UNEP - World Conservation Monitoring Centre, Biodiversity Series No 13. 2003;25.

23. Wakeham SG, Peterson ML, Hedges JI, et al. Lipid biomarker fluxes in the Arabian Sea, with a comparison to the equatorial Pacific Ocean. Deep Res II. 2002;49:2265-2301.

24. Wakeham SG, McNichol AP, Kostka JE, et al. Natural abundance radiocarbon as a tracer of assimilation of petroleum carbon by bacteria in salt marsh sediments. Geochim Cosmochim Acta. 2006;70:1761-1771.

25. Routh J, Gustaf H, Peter K, et al. Multi-proxy study of soil organic matter dynamics in permafrost peat deposits reveal vulnerability to climate change in the European Russian Arctic. Chem Gology. 2014;368:104 - 117.

26. Kim H, Salem, Junior N. Separation of lipid classes by solid phase extraction. J Lipid Res 31 2285-2289. 1990;31:2285-9.

27. Philp RP. Fossil fuel biomarkers. Applications and spectra: methods in geochemistry and geophysics. 23rd ed. Amsterdam: Elsevier; 1985.

28. Peters KE, Walters CC, Moldowan JM. The biomarker guide, biomarkers in petroleum exploration and earth history. 2nd ed. United Kingdom (UK: Cambridge University Press; 2005. 645-705 p.

29. Hedges JI, Stern JH. Carbon and nitrogen determinations of carbonate containing solids. Limnol Oceanogr. 1984;29:657-663.

30. Meziane T, Tsuchiya M. Fatty acids as tracers of organic matter in the sediment and food web of a mangrove/intertidal flat ecosystem, Okinawa, Japan. Mar Ecol Prog Ser. 2000;200:49-57.

31. Meziane T, Tsuchiya M. Organic matter in a subtropical mangrove estuary subjected to wastewater discharge: origin and utilization by two macrozoobenthic species. J Sea Res. 2002;47:1-11.

32. Alfaro AC, Thomas F, Sergent L, et al. Identification of trophic interactions within an estuarine food web (northern New Zealand) using fatty acid biomarkers and stable isotopes. Estuar Coast Shelf Sci. 2006;70:271-286. 
33. Khotimchenko SV. Fatty acids and polar lipids of seagrasses from the Sea of Japan. Phytochemistry. 1993;33:369-372.

34. Kharlamenko VI, Imbs AB, Kiyashko SI, et al. Identification of food sources of invertebrates from the seagrass Zostera marina community using carbon and sulfur stable isotope ratio and fatty acid analyses. Mar Ecol Prog Ser. 2001;220:103-117.

35. Kharlemenko V, Zhukova N, Khotimchenko S, et al. Fatty acids as markers of food sources in a shallow-water hydrothermal ecosystem (Kra- ternaya Bight, Yankich Island, Kurile Islands). Mar Ecol Prog Ser. 1995;120:231-41.

36. Johns RB, Nichols PD, Perry G. Fatty acid composition of ten marine algae from Australian waters. Phytochemistry. 1979;18:799-802.

37. Volkman J, Jeffrey S, Nichols P, et al. Fatty acid and lipid composition of 10 species of microalgae used in mariculture. Mar Biol Ecol. 1989;128:219-240.

38. Parrish CC, Abrajano TA, Budge SM, et al. Lipid and phenolic biomarkers in marine ecosystems: analysis and applications. In: Wangersky $\mathrm{P}$, editor. The handbook of environmental chemistry. 5th ed. Berlin: Springer; 2000. p. 193-223.

39. Mansour MP, Volkman JK, Holdsworth DG, et al. Very-long chain (C28) highly unsaturated fatty acids in marine dinoflagellates. Phytochemistry. 1999;50:541-548.

40. Erftemeijer PLA, Hamerlynck O. Die-back of the mangrove Heritiera littoralis dryland, in the Rufiji Delta (Tanzania) following El Nino floods. Jouranal Coast Res. 2005;42:228-35.

41. Meziane T, Bodineau L, Retiere C, Thoumelin G. The use of lipid markers to define sources of organic matter in sediment and food web of the intertidal salt-marsh-flat ecosystem of Mont-Saint-Michel bay. J Sea Res. 1997;38:47-58.

42. Hall D, Lee S, Meziane T. Fatty acids as trophic tracers in an experimental estuarine food chain: tracer transfer. J Exp Mar Bio Ecol. 2006;336:42-53.

43. Napolitano GE, Pollero RJ, Gayoso AM, et al. Fatty acids as trophic markers of phytoplankton blooms in the Bahia Blanca Estuary (Buenos Aires, Argentina) and in Trinity Bay (Newfoundland, Canada). Biochem Syst Ecol. 1997;25:739- 755.

44. Ito MK, Simpson KL. The biosynthesis of $\omega 3$ fatty acids from 18:2 $\omega 6$ in Artemia spp. Comp Biochem Physiol B. 1996;115:67- 76.

45. Fong P, Boyer KE, Zedler JB. Developing an indicator of nutrient enrichment in coastal estuaries and lagoons using tissue nitrogen content of the opportunistic alga, Enteromorpha intestinalis (L. Link). J Exp Mar Bio Ecol. 1998;231(April 2017):63-79.

46. Carrie RH, Mitchell L, Black KD. Fatty acids in surface sediment at the Hebridean shelf edge, west of Scotland. Org Geochem. 1998;29:1583-1593.

47. Wafar S, Untawale A, Wafar M. Litter fall and energy flux in a mangrove ecosystem. Estuar Coast Shelf Sci. 1997;44:111-124.

48. Shilla D. Fluxes and retention of nutrients and organic carbon in Manko estuary, Okinawa, Japan: influence of river discharge variations. Adv Oceanogr Limnol. 2014;5:141-163. 
49. Cook EJ, Bell M V, Black KD, et al. Fatty acid compositions of gonadal material and diets of the sea urchin, Psammechinus miliaris: trophic and nutritional implications. J Exp Mar Bio Ecol. 2000;255:261-274.

50. Budge SM, Iverson SJ, Bowen WD, et al. Among- and within-species variability in fatty acid signatures of marine fish and invertebrates on the Scotian Shelf, Georges Bank, and southern Gulf of St. Lawrence. Can J Fish Aquat Sci. 2002;59:886-898.

51. Käkelä A, Käkelä SK, Becker PH, et al. Fatty acid signatures in plasma of captive herring gulls as indicators of demersal or pelagic fish diet. Mar Ecol Prog Ser. 2005;293:191-200.

52. Linke TE. Trophic interactions among abundant members of the fish fauna in a permanently-open and a seasonally-open estuary in south-western Australia [thesis]. Murdoch University; 2011.

53. Slim FJ, Ochieng C, Jannink NT, et al. Leaf litter removal by the snail Terebralia palustris (Linnaeus) and Sesarmid crabs in an East African mangrove forest (Gazi Bay, Kenya). J Exp Mar Bio Ecol. 1997;215:35-48.

54. Tenore KR. Organic nitrogen and caloric content of detritus. I. Utilization by the depositfeeding polychaete Capitella capitate. Estuar Coast Shelf Sci. 1981;12:39-47.

55. Tenore KR. Organic nitrogen and caloric content of detritus. 111. Effects on growth of a deposit-feeding polychaete Capitella capitate. Estuar Coast Shelf Sci. 1982;17:733-42.

56. Galap C, Netchitailo P, Leboulenger F, et al. Variations of fatty acid contents in selected tissues of the female dog cockle (Glycyremis glycyremis L., Mollusca, Bivalvia) during the annual cycle. Comp Biochem Physiol A. 1999;122:241-54.

57. Newell RI, Marshall N, Sasekumar A, et al. Relative importance of benthic microalgae, phytoplankton, and mangrove sources of nutrition for penaeid prawns and other coastal invertebrates from Malaysia. Mar Biol. 1995;123:595-606.

58. Lee SY. Carbon dynamics of deep bay, eastern Pearl River estuary, China. II: Trophic relationship based on carbon- and nitrogen-stable isotopes. Mar Ecol Prog Ser. 2000;205:1-10.

59. Kieckbusch DK, Koch MS, Serafy JE, et al. Trophic linkages among primary producers and consumers in fringing mangroves of subtropical lagoons. Bull Mar Sci 74:271-285. 2004;74:271-285.

60. Lee SY, Li MS. Carbon dynamics of deep bay, eastern Pearl River Estuary, China I: A mass balance budget and implications for shorebird conservation. Mar Ecol Prog Ser. 1998;172:73-87.

61. Kristenses E, Alongi DM. Control by fiddler crabs (Uca vocans) and plant roots (Avecennia marina) on carbon, iron, and sulfur biogeochemistry in mangrove sediment”. Limnol Oceanogr. 2006;51:1557 - 1571.

62. Dye AH, Lasiak TA. Microbenthos, meiobenthos and fiddler crabs: trophic interactions in a tropical mangrove sediment. Mar Ecol Prog Ser. 1986;87:341-4.

63. Dye AH, Lasiak T. Assimilation efficiencies of fiddler crabs and deposit feeding 
gastropods from tropical mangrove sediments. Comp Biochem Physiol. 1987;87:341- 344.

64. Leh M, Sasekumar A. Feeding ecology of prawns in shallow water adjoining mangrove shores. In: Soepadmo E, Raol A, Macintosh D, editors. Proceedings of the Asian symposium on mangrove environmental research and management. Kuala Lumpur: University of Malaya; 1984. p. 331-353.

65. Robertson A. Abundance, diets and predators of juvenile Banana prawns Penaeus merguensis, in a tropical mangrove estuary. Aust J Mar Freshw Res. 1988;39:467-478.

66. O’Brien C. Ontogenetic changes in the diets of juvenile brown tiger prawns. Ecol Prog Ser. 1994;112:195-200.

67. Vidal M-L, Basseres A, Narbonne J-F. Seasonal variations of pollution biomarkers in two populations of Corbicula fluminea (Mu“ller). Compar Biochem Physiol Part C. 2002;131:133-151.

68. Bachok Z, Mansor MI, Noordin RM. Diet composition and food habits of demersal and pelagic marine fi shes from Terengganu waters, east coast of Peninsular. NAGA, WorldFish Cent Q. 2004;27(3):41-47.

69. Alam AKM, Mohanty BP, Hoq ME, et al. Nutritional values, consumption and utilization of Hilsa Tenualosa ilisha (Hamilton 1822). In: Proceedings regional workshop on Hilsa: potential for aquaculture. Dhaka, Bangladesh; 2012. p. 16-17.

70. Sargent J, Bell G, McEvoy L, et al. Recent developments in the essential fatty acid nutrition of fish. Aquaculture. 1999;177:191-199.

71. Berg JM, Tymoczko JL, Stryer L. Biochemistry. 5th edit. New York (NY): W. H. Freeman and Company; 2002. 947 p.

72. Hesslein RH, Hallard KA, Ramlal P. Replacement of sulfur, carbon, and nitrogen in tissue of growing broad whitefish (Coregonus nasus) in response to a change in diet traced by $\delta^{34} S, \delta^{13} \mathrm{C}$, and $\delta^{15} \mathrm{~N}$. Can J Fish Aquat Sci. 1993;50:2071-2076.

73. Kennedy H, Gacia ED, Kennedy P, et al. Organic carbon sources to SE Asian coastal sediments. Estuar Coast Shelf Sci. 2004;60:59-68.

74. Vander Zanden MJ, Rasmussen JB. Variation in $\delta^{15} \mathrm{~N}$ and $\delta^{13} \mathrm{C}$ trophic fractionation: implications for aquatic food web studies. Limnol Oceanogr 46 2061-2066. 2001;46:2061-2066.

75. Post DM. Using stable isotopes to estimate trophic position: models, methods, and assumptions. Ecology. 2002;83:703-718.

76. Thimdee W, Deein G, Sangrungruang C, et al. Analysis of primary food sources and trophic relationships of aquatic animals in a mangrove-fringed estuary, Khung Krabaen Bay (Thailand) using dual stable isotope techniques. Wetl Ecol Manag. 2004;12:135-144.

77. Thimdee $\mathrm{W}$, Deein $\mathrm{G}$, Nakayama $\mathrm{N}$, et al. $\delta 13 \mathrm{C}$ and $\delta 15 \mathrm{~N}$ indicators of fish and shrimp community diet and trophic structure in a mangrove ecosystem in Thailand. Wetl Ecol Manag. 2008;16:463-470. 
78. McClelland JW, Michener RH, Valiela I. Nitrogen-stable isotope signatures in estuarine food webs: A record of increasing urbanization in coastal watersheds. Limnol Oceanogr. 1997;42:930-937.

79. McClelland JW, Valiela I. Linking nitrogen in estuarine producers to land-derived sources. Limnol Oceanogr. 1998;43:577-85.

\section{Table captions}

Table 1: Fatty acids used as biomarkers for different food sources.

Table 2: Relative fatty acid composition of potential food sources at Rufiji estuary, Tanzania (\% of the total fatty acids; standard deviations are shown in parentheses; none detected are shown with a dash).

Table 3: Relative fatty acid composition in suspended organic matter (POM) and surface sediment from three locations at Rufiji estuary, Tanzania (\% of the total fatty acids; standard deviations are shown in parentheses; none detected are shown with a dash).

Table 4: Relative fatty acid composition in animal samples from three locations at Rufiji estuary, Tanzania (\% of the total fatty acids; standard deviations are shown in parentheses; none detected are shown with a dash).

Table 5: Means ( \pm SD) of $\delta^{13} \mathrm{C}$ and $\delta^{15} \mathrm{~N}$ composition of potential food sources and consumers from Rufiji Estuary. The range of values are shown in parentheses.

Table S1 (Supplementary data): Relative fatty acid composition in fish samples from three locations at Rufiji estuary, Tanzania (\% of the total fatty acids; standard deviations are shown in parentheses; none detected are shown with a dash).

\section{Figure captions}

Figure 1: Map of the study site at Rufiji Estuary, Tanzania. Three sampling locations are indicated in Muhoro stream (station 1), Msomeni (station 2), and Kalale stream (station 3).

Figure 2: Biomarker composition (percent $\pm \mathrm{SD}$ ) for potential food sources in fish samples $(H$. kelee, T. lepturus and A. thalassinus) collected within three locations at Rufiji Estuary.

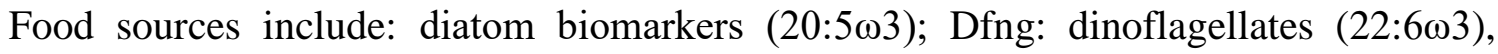

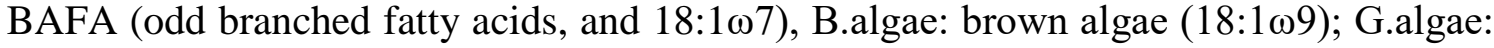

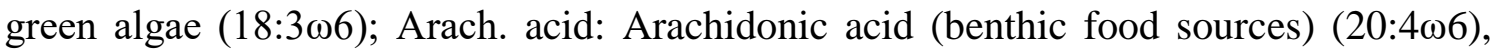
and terrestrial plant (LCFAs).

Figure 3: Non-metric multidimensional scaling ordination (NMS) for the fatty acid profiles of fish invertebrates and organic matter sources. Numbers indicate sampling stations (station 1, 2 and 3), the points without numbers represented the pooled data from all 
sampling stations. All data points in ordination space were presented in average to avoid crowding.

Figure 4: Mean $( \pm \mathrm{SD}) \delta^{15} \mathrm{~N}$ and $\delta^{13} \mathrm{C}$ of potential food sources and consumers from Rufiji Estuary. The food sources include mangrove (Av: Avicennia marina; Her: Heritiera littoralis; and Rhz: Rhizophora mucronata); algae (Ulv: Ulva sp. and Pad: Padina sp.); seagrass (Thl: Thalasia hemprichii); sediment from three stations (SD1, SD2, and SD3); particulate matter (PM1, PM 2, and PM3). The consumers include Pol: polychaetes, gastropods (Ter: Terebralia sp); clams (Cr: Crassostrea cucullata); Crabs (Uc: Uca sp.); Panaeid shrimps (Pan: Panaeus monodon); Teleost (HK: Hilsa kelee, Tl: Trichiurus lepturus and At: Arius thalassinus.

Figure 5: Mean $( \pm \mathrm{SD}) \delta^{15} \mathrm{~N}$ of primary producers and consumers (invertebrates and fish species) in the Rufiji estuary. The primary producers include: Av: Avicennia marina; Her: Heritiera littoralis; Rhz: Rhizophora mucronata; algae, Ulv: Ulva sp.; and Pad: Padina sp.); seagrass, Thl: Thalasia hemprichii. The consumers include: Pol: polychaetes, gastropods (Ter: Terebralia sp), clams (Cr: Crassostrea cucullata), Crabs (Uc: Uca sp, Panaeid shrimps (Pan: Panaeus monodon), Teleost (Hk: Hilsa kelee, Tl: Trichiurus lepturus and At: Arius thalassinus). 


\section{List of Figures}

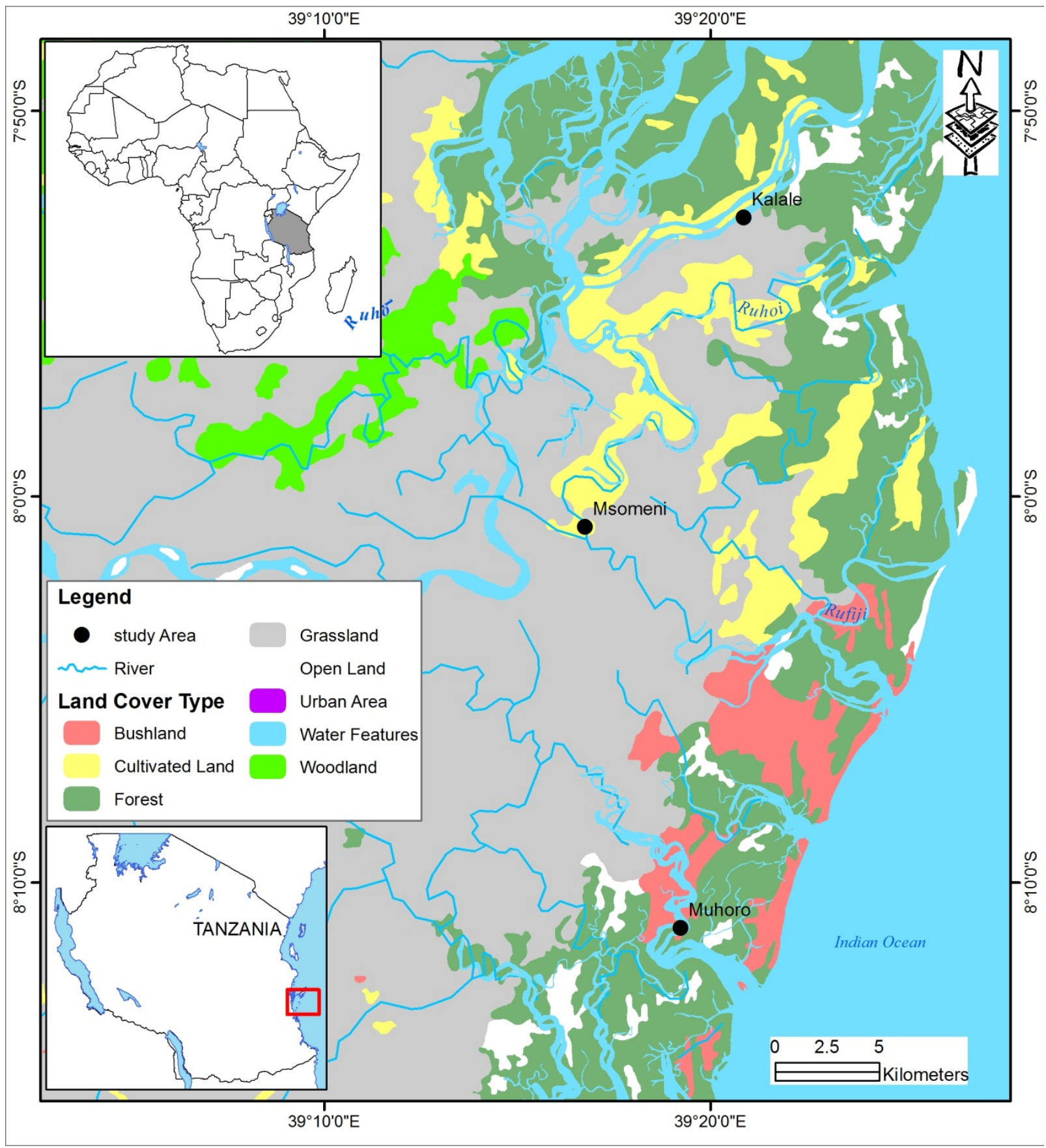

\section{Figure 1}



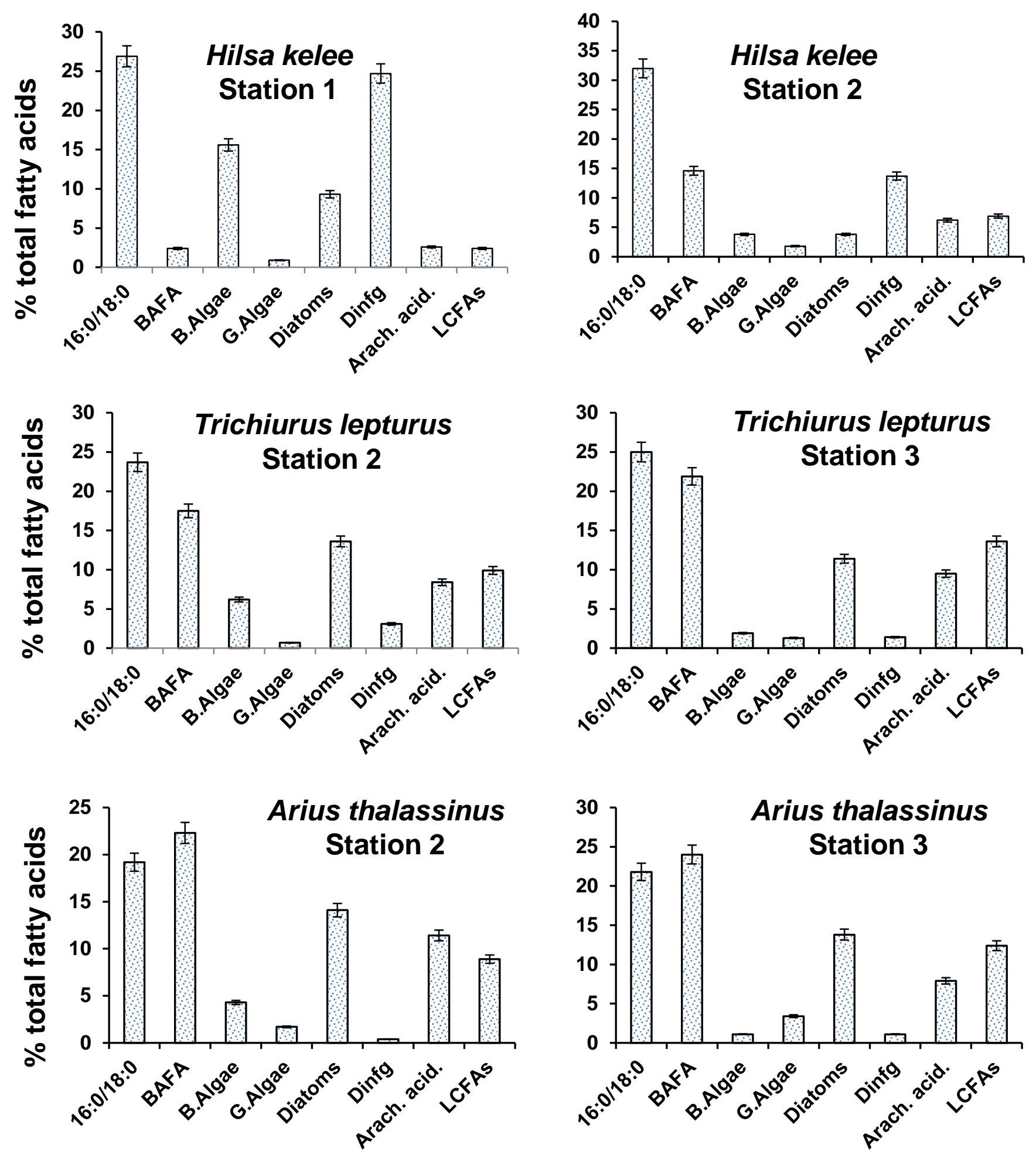

Fig. 2 


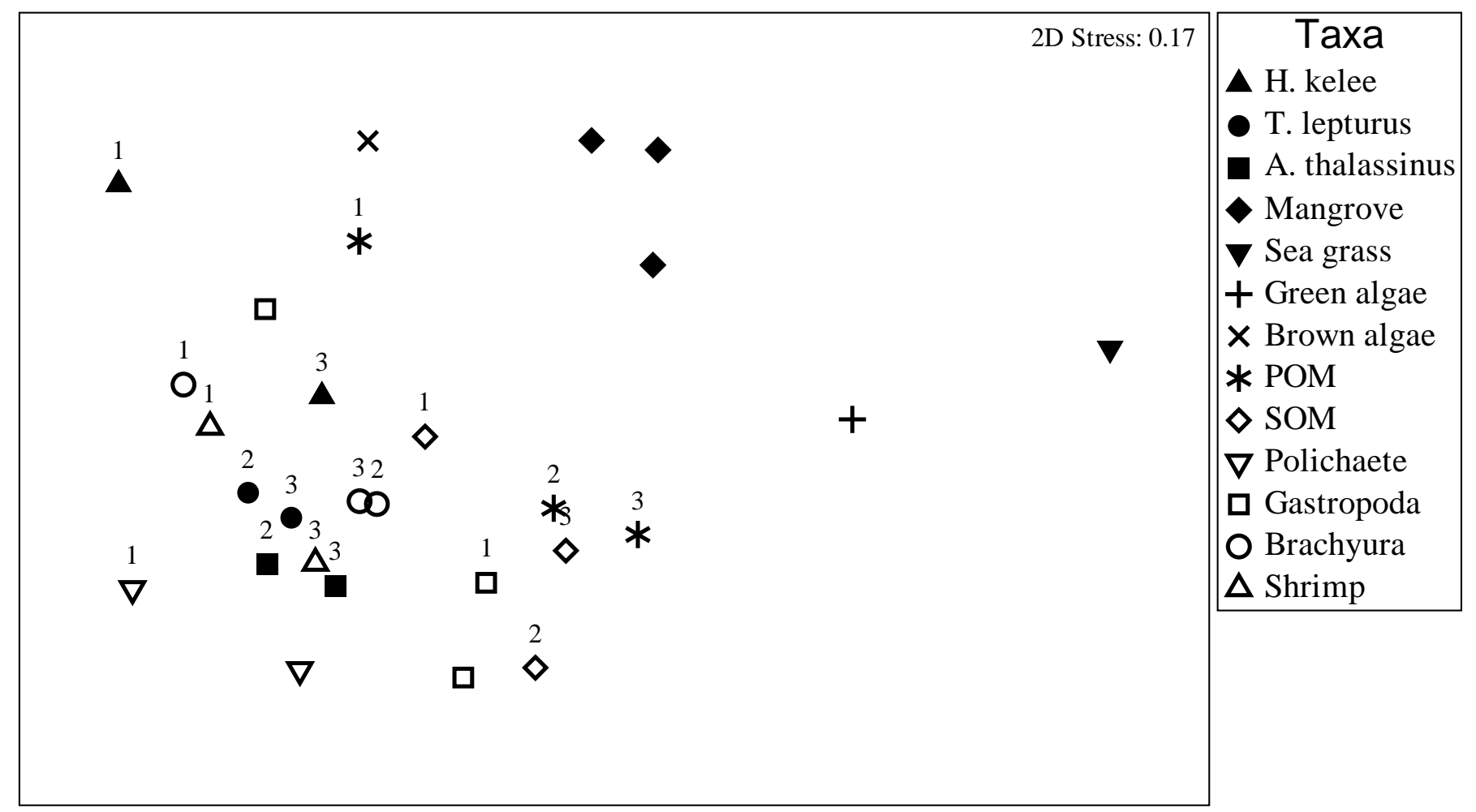

Fig. 3 


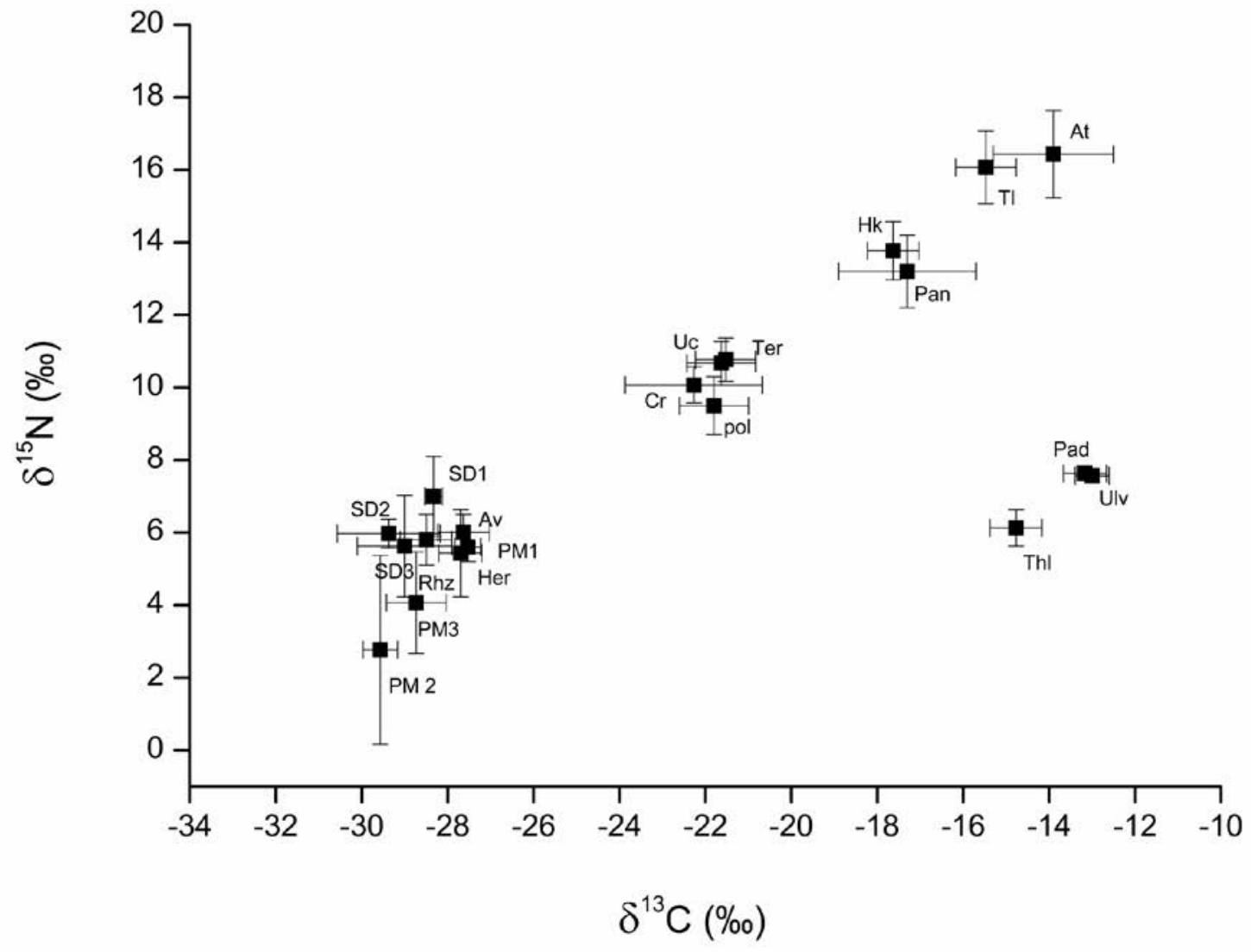

Fig. 4 


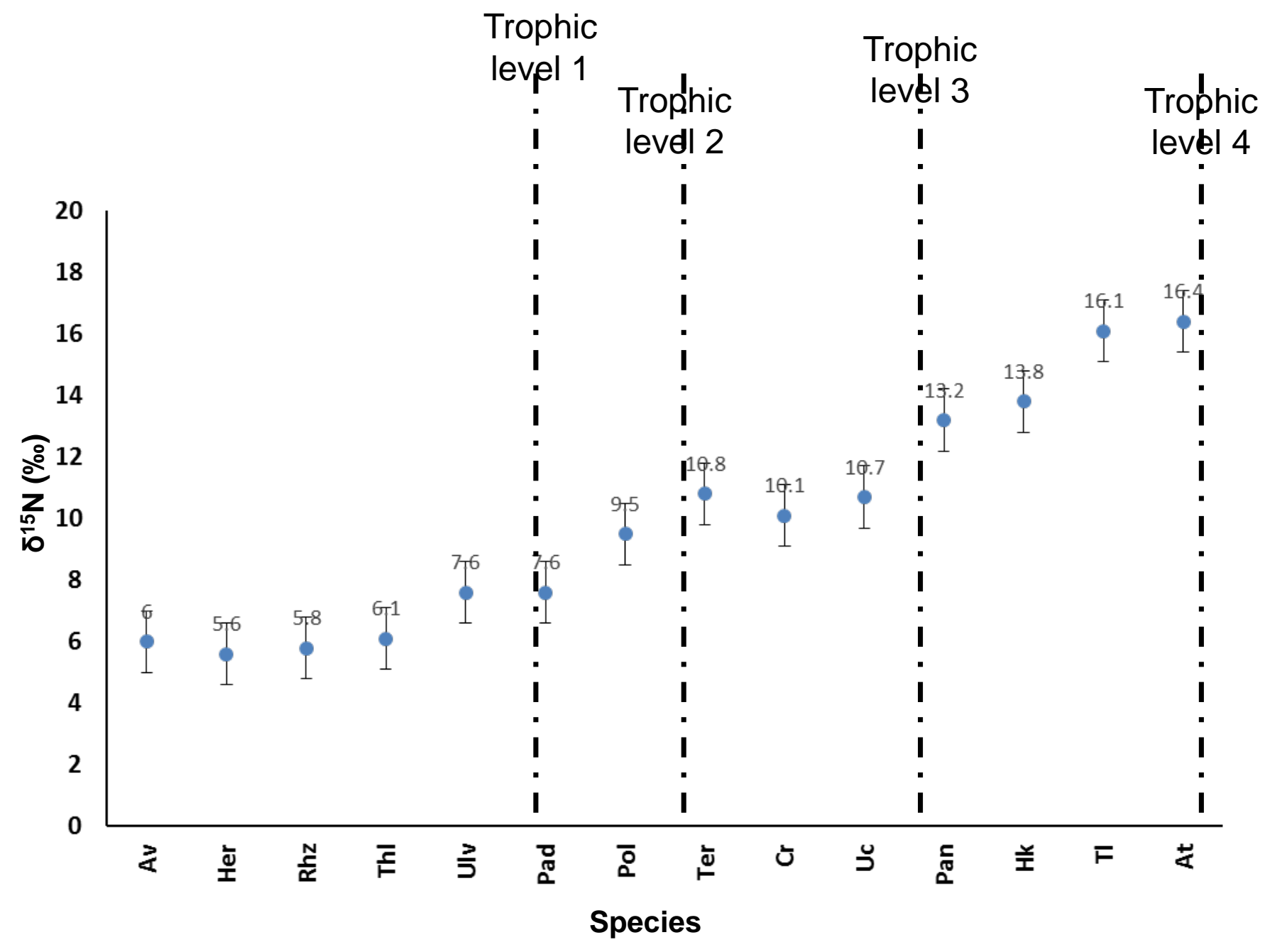

Fig. 5 


\section{List of Tables}

Table 1. Fatty acids used as biomarkers for different food sources.

\begin{tabular}{lll}
\hline Source & Biomarkers & Reference \\
\hline Diatoms & $20: 5 \omega 3$ & Parrish et al. 2000 \\
Dinoflagellates & $22: 6 \omega 3$ & Parrish et al. 2000 \\
Bacteria & $15: O$ iso, 15:O anteiso, 17:O iso, 17:O anteiso, 18:1 $\omega 7$ & Carrie et al. 1998 \\
Terrestrial plants (mangroves) & Long chain fatty acids (LCFAs; fatty acids with more than 24 carbons) & Wannigama et al. \\
& & 1981 \\
Seagrass & $18: 2 \omega 6,18: 3 \omega 3$ & Kharlamenko et al. \\
& & 2001 \\
Brown algae & $18: 1 \omega 9$ & Johns et al. 1979 \\
Green macroalgae & $18: 3 \omega 6,18: 2 \omega 6$, & Kharlamenko et el. \\
& & 1995 \\
\hline
\end{tabular}


Table 2

\begin{tabular}{|c|c|c|c|c|c|c|}
\hline Fatty acids & A. marina & H. littoralis & R. mucronata & T. hemprichii & Ulva sp. & Padina sp. \\
\hline \multicolumn{7}{|l|}{ SFA } \\
\hline $16: 0$ & $28 \pm 1.5$ & $22.3 \pm 2.0$ & $17.4 \pm 1.5$ & $8.3 \pm 1.0$ & $34.7 \pm 3.6$ & $15.4 \pm 1.2$ \\
\hline $18: 0$ & $9.4 \pm 0.9$ & $11.2 \pm 1.0$ & $13.8 \pm 1.1$ & $2.5 \pm 0.5$ & $4.9 \pm 0.8$ & $8.9 \pm 0.8$ \\
\hline Others & $1.2 \pm 0.5$ & $0.7 \pm 0.2$ & $3.2 \pm 0.4$ & $7.8 \pm 2.1$ & $0.9 \pm 0.2$ & $3.2 \pm 0.2$ \\
\hline Sum (\%) & $38.6 \pm 2.1$ & $34.2 \pm 1.6$ & $35.3 \pm 1.4$ & $18.6 \pm 1.2$ & $40.5 \pm 3.2$ & $27.5 \pm 1.7$ \\
\hline \multicolumn{7}{|l|}{ BAFA } \\
\hline $15: 0$ anteiso & $0.3 \pm 0.4$ & - & - & - & - & - \\
\hline $17: 0$ iso & $0.8 \pm 0.2$ & - & $0.3 \pm 0.2$ & $0.2 \pm 0.1$ & $2.3 \pm 0.2$ & - \\
\hline 17:0 anteiso & - & $1.8 \pm 0.6$ & - & - & - & - \\
\hline Sum (\%) & $1.1 \pm 0.5$ & $1.8 \pm 0.5$ & $0.3 \pm 0.1$ & $0.2 \pm 0.3$ & $2.3 \pm 1.0$ & $\mathbf{0} \pm \mathbf{0 . 0}$ \\
\hline \multicolumn{7}{|l|}{ MUFA } \\
\hline $17: 01$ & $0.3 \pm 0.2$ & - & - & $1.2 \pm 0.2$ & - & $0.8 \pm 0.2$ \\
\hline $18: 1 \omega 9$ & $4.7 \pm 0.7$ & $3.2 \pm 0.7$ & $11.1 \pm 1.1$ & $4.5 \pm 0.9$ & $5.2 \pm 0.8$ & $22.6 \pm 2.4$ \\
\hline $18: 1 \omega 7$ & $0.4 \pm 0.2$ & - & - & $1.3 \pm 0.5$ & $2.7 \pm 0.2$ & $3.4 \pm 0.8$ \\
\hline Others & $0.7 \pm 0.2$ & $1.7 \pm 0.3$ & $3.3 \pm 0.4$ & $1.6 \pm 0.5$ & $2.5 \pm 0.6$ & $1.3 \pm 0.7$ \\
\hline Sum (\%) & $5.8 \pm 0.8$ & $4.9 \pm 0.9$ & $14.4 \pm 1.2$ & $7.4 \pm 1.1$ & $10.4 \pm 1.1$ & $27.3 \pm 3.2$ \\
\hline \multicolumn{7}{|l|}{ PUFA } \\
\hline $18: 2 \omega 6$ & $6.7 \pm 0.6$ & $1.6 \pm 0.3$ & $0.7 \pm 0.2$ & $24.2 \pm 2.2$ & $12.7 \pm 1.2$ & $3.8 \pm 0.4$ \\
\hline $18: 3 \omega 6$ & $7.1 \pm 0.6$ & $2.3 \pm 0.5$ & $5.7 \pm 0.5$ & $16.4 \pm 2.8$ & $28.9 \pm 2.1$ & $11.2 \pm 1.1$ \\
\hline $18: 3 \omega 4$ & - & $0.4 \pm 0.2$ & - & - & $0.7 \pm 0.2$ & - \\
\hline $18: 3 \omega 3$ & $4.8 \pm 0.8$ & $11.8 \pm 1.2$ & $3.8 \pm 0.6$ & $27.8 \pm 3.2$ & $2.8 \pm 0.8$ & $7.6 \pm 0.9$ \\
\hline $20: 4 \omega 6$ & - & $0.3 \pm 0.1$ & $0.7 \pm 0.3$ & - & $0.6 \pm 0.2$ & $16.4 \pm 1.2$ \\
\hline $20: 5 \omega 3$ & - & - & - & - & - & $4.7 \pm 1.0$ \\
\hline $22: 6 \omega 3$ & $0.4 \pm 0.1$ & - & - & - & - & - \\
\hline Others & $0.8 \pm 0.6$ & $0.2 \pm 0.7$ & $0.0 \pm 0.0$ & $1.3 \pm 0.3$ & $0.5 \pm 0.1$ & $0.6 \pm 0.11$ \\
\hline Sum (\%) & $19.8 \pm 1.2$ & $16.6 \pm 0.9$ & $10.9 \pm 1.0$ & $69.7 \pm 4.6$ & $46.2 \pm 3.6$ & $44.3 \pm 4.1$ \\
\hline \multicolumn{7}{|l|}{ LCFA } \\
\hline Sum (\%) & $34.8 \pm 2.4$ & $42.5 \pm 2.4$ & $39.1 \pm 1.8$ & $3.5 \pm 1.1$ & $0.6 \pm 0.1$ & $0.9 \pm 0.3$ \\
\hline $\begin{array}{l}\text { Total FAMEs } \\
\text { ( } \mu \mathrm{g} / \mathrm{g} \text { dry wt) }\end{array}$ & $482.4 \pm 14.6$ & $609.7 \pm 12.6$ & $658.3 \pm 10.9$ & $821.8 \pm 25.8$ & $233.7 \pm 14.1$ & $263.5 \pm 10.2$ \\
\hline
\end{tabular}


Table 3

\begin{tabular}{|c|c|c|c|c|c|c|}
\hline \multirow[b]{2}{*}{ Fatty acids } & \multicolumn{3}{|c|}{ POM } & \multicolumn{3}{|c|}{ Sediment (SOM) } \\
\hline & Station 1 & Station 2 & Station 3 & Station 1 & Station 2 & Station 3 \\
\hline \multicolumn{7}{|l|}{ SFA } \\
\hline $16: 0$ & $16.7 \pm 1.1$ & $19.1 \pm 0.2$ & $22.9 \pm 1.8$ & $18.1 \pm 1.3$ & $21.9 \pm 5.2$ & $18.6 \pm 2.1$ \\
\hline 18:0 & $12.7 \pm 1.1$ & $15.6 \pm 0.9$ & $13.9 \pm 0.7$ & $10.4 \pm 1.1$ & $17.8 \pm 2.8$ & $15.6 \pm 2.4$ \\
\hline Others (\%) & $7.9 \pm 0.8$ & $4.3 \pm 0.9$ & $10.0 \pm 0.10$ & $4.3 \pm 0.11$ & $0.0 \pm 0.0$ & $5.2 \pm 0.13$ \\
\hline Sum (\%) & $37.3 \pm 1.8$ & $39 \pm 2.4$ & $46.8 \pm 2.1$ & $32.8 \pm 3.4$ & $39.7 \pm 4.5$ & $39.4 \pm 3.2$ \\
\hline \multicolumn{7}{|l|}{ BFA } \\
\hline $15: 0$ anteiso & $2.2 \pm 0.6$ & $4.2 \pm 0.8$ & $2.0 \pm 0.4$ & $6.8 \pm 1.0$ & $6.5 \pm 0.9$ & - \\
\hline $17: 0$ iso & $1.8 \pm 0.9$ & $3.5 \pm 0.5$ & - & $4.6 \pm 0.4$ & $4.7 \pm 0.5$ & $7.1 \pm 1.4$ \\
\hline 17:0 anteiso & - & $0.8 \pm 0.2$ & $4.1 \pm 1.0$ & $0.5 \pm 0.4$ & $3.3 \pm 0.2$ & $4.9 \pm 1.2$ \\
\hline Sum (\%) & $4 \pm 0.8$ & $8.5 \pm 1.1$ & $6.1 \pm 1.2$ & $11.9 \pm 1.1$ & $14.5 \pm 2.2$ & $12 \pm 3.1$ \\
\hline \multicolumn{7}{|l|}{ MUFA } \\
\hline $17: 01$ & $0.8 \pm 0.3$ & $0.6 \pm 0.1$ & - & $0.3 \pm 0.3$ & $0.3 \pm 0.5$ & - \\
\hline $18: 1 \omega 9$ & $4.9 \pm 1.0$ & $2.4 \pm 0.7$ & $1.8 \pm 0.6$ & $6.9 \pm 0.7$ & $0.2 \pm 0.1$ & $3.5 \pm 0.7$ \\
\hline $18: 1 \omega 7$ & $7.14 \pm 1.1$ & $14.8 \pm 1.0$ & $12.6 \pm 1.5$ & $12 \pm 2.2$ & $17.3 \pm 2.1$ & $14.9 \pm 3.6$ \\
\hline Others (\%) & $8.2 \pm 0.3$ & $3.1 \pm 0.4$ & $0.9 \pm 0.5$ & $0.6 \pm 0.1$ & $0.0 \pm 0.0$ & $0.8 \pm 0.4$ \\
\hline Sum (\%) & $21.04 \pm 1.6$ & $20.9 \pm 2.3$ & $15.3 \pm 3.4$ & $21.04 \pm 3.4$ & $17.8 \pm 2.4$ & $19.2 \pm 2.7$ \\
\hline \multicolumn{7}{|l|}{ PUFA } \\
\hline $18: 2 \omega 6$ & $1.7 \pm 0.3$ & $10.1 \pm 1.8$ & $14.7 \pm 2.3$ & $3.8 \pm 0.5$ & $13.9 \pm 3.2$ & $12 \pm 1.4$ \\
\hline $18: 3 \omega 6$ & $3.5 \pm 0.6$ & $10.9 \pm 0.9$ & $9.6 \pm 1.2$ & $0.8 \pm 0.4$ & $2.1 \pm 1.2$ & $3.7 \pm 0.6$ \\
\hline $18: 3 \omega 3$ & $4.8 \pm 0.9$ & $0.6 \pm 0.1$ & $0.7 \pm 0.2$ & $7.8 \pm 0.4$ & - & $0.4 \pm 0.2$ \\
\hline $20: 4 \omega 6$ & $0.7 \pm 0.2$ & - & $0.4 \pm 0.1$ & - & - & - \\
\hline $20: 3 \omega 3$ & $0.2 \pm 0.1$ & - & - & - & - & - \\
\hline $20: 5 \omega 3$ & $4.6 \pm 0.5$ & $2.6 \pm 0.4$ & $0.9 \pm 0.2$ & $15.1 \pm 3.3$ & $3.2 \pm 1.2$ & $1.3 \pm 0.6$ \\
\hline $22: 6 \omega 3$ & $19.3 \pm 1.2$ & $1.5 \pm 0.5$ & $0.5 \pm 0.2$ & $0.2 \pm 0.1$ & $0.3 \pm 0.1$ & - \\
\hline Others (\%) & $0.0 \pm 0.0$ & $0.8 \pm 0.3$ & $0.5 \pm 0.4$ & $1.1 \pm 0.5$ & $0.0 \pm 0.0$ & $1.0 \pm 0.7$ \\
\hline Sum (\%) & $34.8 \pm 3.2$ & $26.5 \pm 2.2$ & $27.3 \pm 3.1$ & $28.8 \pm 3.2$ & $19.5 \pm 1.8$ & $18.4 \pm 4.2$ \\
\hline \multicolumn{7}{|l|}{ LCFA } \\
\hline Sum (\%) & $2.8 \pm 0.9$ & $5.1 \pm 2.2$ & $4.5 \pm 0.9$ & $5.9 \pm 1.0$ & $8.5 \pm 0.9$ & $11 \pm 1.0$ \\
\hline $\begin{array}{l}\text { Total FAMEs } \\
\text { ( } \mu \mathrm{g} / \mathrm{g} \text { dry wt) }\end{array}$ & $159.5 \pm 14.8$ & $233.1 \pm 8.2$ & $187.4 \pm 21.2$ & $312.7 \pm 12.1$ & $334.9 \pm 9.2$ & $368.7 \pm 34.4$ \\
\hline
\end{tabular}


Table 4.

\begin{tabular}{|c|c|c|c|c|c|c|c|c|c|c|}
\hline \multirow{2}{*}{$\begin{array}{l}\text { Fatty acids } \\
\text { SFA }\end{array}$} & \multicolumn{2}{|c|}{ Polychaete } & \multicolumn{2}{|c|}{ Terebralia spp } & \multirow{2}{*}{$\begin{array}{l}\text { C. cucullata } \\
\text { All } 3 \text { stations }\end{array}$} & \multicolumn{3}{|c|}{ Uca sp } & \multicolumn{2}{|c|}{ Panaeus monodon } \\
\hline & Station 1 & Station $2 \& 3$ & Station 1 & Station $2 \& 3$ & & Station 1 & Station 2 & Station 3 & Station 1 & Station 3 \\
\hline $16: 00$ & $11.8 \pm 2.5$ & $14.5 \pm 3.8$ & $18.4 \pm 1.8$ & $15.3 \pm 2.56$ & $22.1 \pm 2.6$ & $26.6 \pm 7.0$ & $29.6 \pm 8.2$ & $26.3 \pm 6.5$ & $17.6 \pm 2.5$ & $14.8 \pm 08$ \\
\hline $17: 00$ & $1.4 \pm 1.0$ & $0.4 \pm 0.2$ & - & $1.5 \pm 0.6$ & $1.2 \pm 0.8$ & $2.8 \pm 2.0$ & $0.9 \pm 0.1$ & $1.1 \pm 0.5$ & $0.6 \pm 0.1$ & $0.6 \pm 0.5$ \\
\hline 18:00 & $8.6 \pm 1.2$ & $9.2 \pm 1.2$ & $10.2 \pm 2.1$ & $6.8 \pm 1.5$ & $11.4 \pm 2.6$ & $5.7 \pm 1.1$ & $10.1 \pm 1.4$ & $7.4 \pm 1.5$ & $6.1 \pm 0.8$ & $7.2 \pm 4.0$ \\
\hline Others (\%) & $1.1 \pm 1.0$ & $1.2 \pm 1.0$ & $4.5 \pm 1.2$ & $2.5 \pm 1.3$ & $4.1 \pm 1.4$ & $5.3 \pm 1.2$ & $1.5 \pm 0.6$ & $2.4 \pm 1.1$ & $2.9 \pm 1.8$ & $2.3 \pm 1.9$ \\
\hline Sum (\%) & $22.9 \pm 5.1$ & $25.3 \pm 3.4$ & $33.4 \pm 7.5$ & $26.1 \pm 4.2$ & $38.8 \pm 4.7$ & $40.4 \pm 6.5$ & $42.1 \pm 9.1$ & $37.2 \pm 10.4$ & $27.2 \pm 8.2$ & $24.9 \pm 6.8$ \\
\hline \multicolumn{11}{|l|}{ BFA } \\
\hline 15:0 anteiso & $2.2 \pm 0.8$ & $2.1 \pm 0.8$ & $18.78 \pm 6.2$ & $21.4 \pm 10.7$ & $0.5 \pm 0.2$ & $2.4 \pm 0.8$ & $7.0 \pm 0.2$ & $9.1 \pm 1.1$ & $3.4 \pm 0.3$ & $7.2 \pm 1.3$ \\
\hline $17: 0$ iso & $5.2 \pm 0.8$ & $9.9 \pm 2.1$ & $6.4 \pm 0.7$ & $4.8 \pm 1.2$ & $0.8 \pm 0.2$ & $4.0 \pm 0.7$ & $1.9 \pm 1.4$ & $3.8 \pm 0.8$ & $2.2 \pm 0.9$ & $4.4 \pm 1.5$ \\
\hline 17:0 anteiso & $1.1 \pm 0.4$ & $8.4 \pm 0.9$ & $2.2 \pm 0.5$ & $6.1 \pm 1.1$ & $1.3 \pm 0.6$ & $0.4 \pm 0.2$ & $4.3 \pm 1.2$ & $4.6 \pm 1.6$ & $2.7 \pm 1.2$ & $4.7 \pm 2.2$ \\
\hline Sum (\%) & $8.5 \pm 2.8$ & $20.4 \pm 2.5$ & $27.4 \pm 4.2$ & $32.3 \pm 7.6$ & $2.6 \pm 1.2$ & $6.8 \pm 2.1$ & $13.2 \pm 6.1$ & $17.5 \pm 3.7$ & $8.3 \pm 3.4$ & $16.3 \pm 3.8$ \\
\hline \multicolumn{11}{|l|}{ MUFA } \\
\hline $17: 01$ & - & $0.4 \pm 0.2$ & - & $0.9 \pm 0.2$ & - & $2.6 \pm 0.7$ & $0.5 \pm 0.2$ & $1.8 \pm 0.7$ & - & $0.4 \pm 0.2$ \\
\hline $18: 1 \omega 9$ & $1.9 \pm 0.5$ & $0.6 \pm 0.5$ & - & $0.4 \pm 0.4$ & $6.6 \pm 0.45$ & $8.1 \pm 1.7$ & $1.7 \pm 1.0$ & $1.6 \pm 0.9$ & $12.2 \pm 2.9$ & $2.8 \pm 0.8$ \\
\hline $18: 1 \omega 7$ & $6.6 \pm 1.2$ & $9.2 \pm 1.0$ & $3.9 \pm 1.1$ & $8.7 \pm 0.8$ & $1.3 \pm 0.2$ & $1.2 \pm 0.9$ & $5.3 \pm 2.3$ & $1.4 \pm 1.5$ & $3.6 \pm 2.2$ & $10.9 \pm 3.3$ \\
\hline Others (\%) & $4.6 \pm 1.5$ & $0.6 \pm 0.1$ & $2.0 \pm 0.7$ & $2.0 \pm 0.8$ & $1.7 \pm 0.9$ & $6.8 \pm 0.1$ & $0.7 \pm 0.1$ & $1.5 \pm 2.0$ & $3.8 \pm 1.2$ & $2.4 \pm 0.4$ \\
\hline Sum (\%) & $13.1 \pm 1.4$ & $10.8 \pm 2.8$ & $5.9 \pm 1.2$ & $12 \pm 1.2$ & $9.6 \pm 2.7$ & $18.7 \pm 4.1$ & $8.2 \pm 1.1$ & $6.3 \pm 0.5$ & $19.6 \pm 4.6$ & $16.5 \pm 5.8$ \\
\hline \multicolumn{11}{|l|}{ PUFA } \\
\hline $18: 2 \omega 6$ & $2.8 \pm 0.8$ & $6.8 \pm 1.8$ & $2.3 \pm 0.4$ & $5.6 \pm 1.4$ & $0.5 \pm 0.2$ & $1.2 \pm 0.8$ & $3.8 \pm 1.2$ & $1.9 \pm 0.8$ & $0.7 \pm 0.2$ & $1.2 \pm 0.8$ \\
\hline $18: 3 \omega 6$ & $6.7 \pm 0.9$ & $1.4 \pm 0.8$ & $11.6 \pm 0.8$ & $8.5 \pm 0.8$ & $2.8 \pm 2.3$ & - & $1.3 \pm 0.8$ & $1.6 \pm 0.4$ & $0.6 \pm 0.1$ & $0.8 \pm 0.5$ \\
\hline $18: 3 \omega 3$ & $3.4 \pm 0.4$ & $0.5 \pm 0.2$ & $1.1 \pm 0.6$ & - & - & $0.9 \pm 0.3$ & - & - & $0.9 \pm 0.3$ & - \\
\hline $20: 4 \omega 6$ & $27.1 \pm 3.6$ & $19.4 \pm 2.5$ & $3.4 \pm 0.9$ & $1.5 \pm 0.5$ & $7.7 \pm 1.3$ & $8.2 \pm 2.6$ & $7.1 \pm 0.4$ & $6.6 \pm 0.8$ & $11.6 \pm 5.6$ & $12.5 \pm 4.5$ \\
\hline $20: 5 \omega 3$ & $14.2 \pm 2.4$ & $5.3 \pm 0.8$ & $2.5 \pm 0.7$ & $0.9 \pm 0.2$ & $9.2 \pm 1.4$ & $15.5 \pm 1.7$ & $6.7 \pm 0.9$ & $5.4 \pm 1.2$ & $15.7 \pm 2.0$ & $6.7 \pm 1.5$ \\
\hline $22: 6 \omega 3$ & - & - & - & - & $20.1 \pm 4.1$ & $0.4 \pm 0.2$ & - & $0.5 \pm 0.2$ & $4.5 \pm 1.3$ & $1.7 \pm 1.5$ \\
\hline Others (\%) & $6.5 \pm 1.8$ & $2.8 \pm 1.5$ & $3.5 \pm 0.8$ & $1.1 \pm 0.1$ & $1.8 \pm 1.2$ & $1.9 \pm 0.7$ & $2.7 \pm 1.1$ & $3.5 \pm 1.2$ & $0.0 \pm 0.0$ & $2.5 \pm 1.2$ \\
\hline Sum (\%) & $60.7 \pm 6.7$ & $36.2 \pm 5.7$ & $24.4 \pm 4.2$ & $17.6 \pm 4.2$ & $42.1 \pm 8.2$ & $28 \pm 8.6$ & $21.6 \pm 5.3$ & $19.5 \pm 3.1$ & $34 \pm 7.8$ & $25.4 \pm 8.3$ \\
\hline \multicolumn{11}{|l|}{ LCFA } \\
\hline Sum (\%) & $2.8 \pm 1.0$ & $7.3 \pm 0.2$ & $8.9 \pm 2.4$ & $12 \pm 2.6$ & $6.9 \pm 2.1$ & $5.3 \pm 2.1$ & $14.9 \pm 3.2$ & $19.5 \pm 6.1$ & $11 \pm 6.2$ & $16.9 \pm 1.7$ \\
\hline $\begin{array}{l}\text { Total FAMEs } \\
\text { ( } \mu \mathrm{g} / \mathrm{g} \text { dry } w \mathrm{t})\end{array}$ & $1223.3 \pm 57.9$ & $1411.7 \pm 43.8$ & $1804.9 \pm 81.8$ & $1786.4 \pm 76.5$ & $1503.8 \pm 37.8$ & $1393.5 \pm 56.8$ & $1402.5 \pm 16.8$ & $1413.6 \pm 49.5$ & $1398.7 \pm 91.2$ & $1402.4 \pm 52.7$ \\
\hline
\end{tabular}

Note: For statistically similar ( $>0.05$ ) stations, FAs profiles are given as averages for stations where samples was collected from 
Table 5

\begin{tabular}{|c|c|c|}
\hline Species & $13 \mathrm{C}$ & $15 N$ \\
\hline \multicolumn{3}{|l|}{ Primary producers } \\
\hline Avicennia marina & $\begin{array}{c}-27.6 \pm 0.6 \\
(-27.3 \text { to }-28.1)\end{array}$ & $\begin{array}{c}6.0 \pm 0.5 \\
(5.6 \text { to } 6.6)\end{array}$ \\
\hline Heritiera littoralis, & $\begin{array}{c}27.5 \pm 0.3 \\
(-26.4 \text { to }-28.8)\end{array}$ & $\begin{array}{c}5.6 \pm 0.4 \\
(5.2 \text { to } 5.8)\end{array}$ \\
\hline Rhizophora mucronata & $\begin{array}{c}-28.5 \pm 0.6 \\
(-27.3 \text { to }-29.4)\end{array}$ & $\begin{array}{c}5.8 \pm 0.7 \\
(5.4 \text { to } 6.1)\end{array}$ \\
\hline Thalasia hemprichii & $\begin{array}{c}-14.8 \pm 0.6 \\
(-15.8 \text { to }-12.8)\end{array}$ & $\begin{array}{c}6.1 \pm 0.5 \\
\text { (5.9 to } 6.8)\end{array}$ \\
\hline Ulva sp & $\begin{array}{c}-13.0 \pm 0.4 \\
(-13.7 \text { to }-11.9)\end{array}$ & $\begin{array}{c}7.6 \pm 0.2 \\
\text { (7.4 to } 7.8)\end{array}$ \\
\hline Padina sp & $\begin{array}{c}-13.2 \pm 0.5 \\
(-14.6 \text { to }-11.3)\end{array}$ & $\begin{array}{c}7.6 \pm 0.2 \\
\text { (7.3 to } 7.8)\end{array}$ \\
\hline POM & & \\
\hline station 1 & $\begin{array}{c}-27.7 \pm 0.5 \\
(-28.2 \text { to }-27.4)\end{array}$ & $\begin{array}{c}5.4 \pm 1.2 \\
(4.3 \text { to } 7.4)\end{array}$ \\
\hline Station 2 & $\begin{array}{c}-29.6 \pm 0.4 \\
(-30.7 \text { to }-28.1)\end{array}$ & $\begin{array}{c}2.8 \pm 2.6 \\
(-0.92 \text { to } 4.8)\end{array}$ \\
\hline Station 3 & $\begin{array}{c}-28.7 \pm 0.7 \\
(-29.9 \text { to }-27.6)\end{array}$ & $\begin{array}{c}4.1 \pm 1.4 \\
(2.7 \text { to } 5.2)\end{array}$ \\
\hline Sediment & & \\
\hline Station 1 & $\begin{array}{c}-28.3 \pm 0.2 \\
(-28.6 \text { to }-28.1)\end{array}$ & $\begin{array}{c}7.0 \pm 1.1 \\
(5.7 \text { to } 8.5)\end{array}$ \\
\hline Station 2 & $\begin{array}{c}-29.4 \pm 1.2 \\
(-30.7 \text { to }-28.3)\end{array}$ & $\begin{array}{c}6.0 \pm 0.4 \\
\text { (5.7 to } 6.3)\end{array}$ \\
\hline Station 3 & $\begin{array}{c}29.0 \pm 1.1 \\
(-30.2 \text { to }-27.1)\end{array}$ & $\begin{array}{c}5.6 \pm 1.4 \\
(4.6 \text { to } 6.6)\end{array}$ \\
\hline
\end{tabular}

\begin{tabular}{lcc}
\hline \multicolumn{1}{c}{ Species } & $\mathbf{1 3 C}$ & $\mathbf{1 5 N}$ \\
\hline Consumers & & \\
polychaetes & $-21.8 \pm 0.8$ & $9.5 \pm 0.8$ \\
& $(-23.2$ to -20.1$)$ & $(8.7$ to 10.4$)$ \\
Terebralia sp & $-21.5 \pm 0.7$ & $10.8 \pm 0.6$ \\
& $(-22.6$ to -20.7$)$ & $(10.2$ to 11.6$)$ \\
Crassostrea cucullata & $-22.3 \pm 1.6$ & $10.1 \pm 0.5$ \\
& $(-23.3$ to -21.7$)$ & $(9.4$ to 10.9$)$ \\
Uca sp & $-21.6 \pm 0.8$ & $10.7 \pm 0.6$ \\
& $(-22.4$ to -21.2$)$ & $(10.3$ to 11.8$)$ \\
Panaeus monodon & $-17.3 \pm 1.6$ & $13.2 \pm 1.0$ \\
& $(-18.7$ to -15.5$)$ & $(12.7$ to 13.6$)$ \\
Hilsa kelee & $-27.6 \pm 0.6$ & $13.8 \pm 0.8$ \\
& $(-21.2$ to -15.3$)$ & $(13.4$ to 14.2$)$ \\
Trichiurus lepturus & $-15.5 \pm 0.7$ & $16.1 \pm 1.0$ \\
& $(-16.4$ to -14.8$)$ & $(15.6$ to 16.4$)$ \\
Arius thalassinus & $-13.9 \pm 1.4$ & $16.4 \pm 1.2$ \\
& $(-15.3$ to -12.8$)$ & $(15.9$ to 16.9$)$ \\
\hline
\end{tabular}


Table S1 (Supplementary data)

\begin{tabular}{|c|c|c|c|c|c|c|}
\hline \multirow[b]{2}{*}{ Fatty acids } & \multicolumn{2}{|c|}{ Hilsa kelee } & \multicolumn{2}{|c|}{ Trichiurus lepturus } & \multicolumn{2}{|c|}{ Arius thalassinus } \\
\hline & Station 1 & Station 3 & Station 2 & Station 3 & Station 2 & Station 3 \\
\hline \multicolumn{7}{|l|}{ SFA } \\
\hline $14: 0$ & $1.1 \pm 0.5$ & $0.7 \pm 0.3$ & $2.2 \pm 1.3$ & $0.6 \pm 0.1$ & - & $1.4 \pm 0.8$ \\
\hline $16: 0$ & $19.5 \pm 4.7$ & $23.2 \pm 4.7$ & $13.4 \pm 3.9$ & $17.4 \pm 4.2$ & $14.6 \pm 8.3$ & $15.7 \pm 6.2$ \\
\hline $17: 0$ & $0.3 \pm 1.2$ & - & $0.4 \pm 0.2$ & $0.7 \pm 0.4$ & $0.8 \pm 0.8$ & - \\
\hline 18:0 & $7.4 \pm 1.1$ & $8.8 \pm 2.8$ & $10.3 \pm 6.1$ & $7.6 \pm 3.8$ & $4.6 \pm 1.9$ & $6.1 \pm 1.5$ \\
\hline Others (\%) & $1.0 \pm 0.2$ & $1.5 \pm 1.3$ & $1.8 \pm 1.0$ & $2.5 \pm 1.5$ & $2.5 \pm 1.6$ & $0.8 \pm 0.4$ \\
\hline Sum (\%) & $29.3 \pm 11.1$ & $34.2 \pm 9.2$ & $28.1 \pm 7.4$ & $28.8 \pm 12.7$ & $22.5 \pm 5.6$ & $24 \pm 11.3$ \\
\hline \multicolumn{7}{|l|}{ BFA } \\
\hline 15:0 anteiso & $1.0 \pm 0.8$ & $4.0 \pm 0.2$ & $4.3 \pm 1.4$ & $7.5 \pm 3.1$ & $5.9 \pm 2.0$ & $8.5 \pm 4.1$ \\
\hline $17: 0$ iso & $0.7 \pm 0.2$ & $2.6 \pm 0.8$ & $4.7 \pm 0.8$ & $1.9 \pm 0.2$ & $5.5 \pm 6.1$ & $2.9 \pm 1.0$ \\
\hline 17:0 anteiso & - & $0.8 \pm 0.3$ & $2.9 \pm 0.9$ & $3.8 \pm 0.7$ & $4.7 \pm 2.7$ & $3.7 \pm 2.1$ \\
\hline Sum (\%) & $1.7 \pm 0.9$ & $7.4 \pm 2.1$ & $11.9 \pm 6.4$ & $13.2 \pm 5.6$ & $16.1 \pm 9.2$ & $15.1 \pm 3.9$ \\
\hline \multicolumn{7}{|l|}{ MUFA } \\
\hline $16: 1 \omega 7$ & $0.5 \pm 0.4$ & $1.3 \pm 0.9$ & - & $3.8 \pm 1.4$ & $0.6 \pm 0.2$ & $0.6 \pm 0.9$ \\
\hline $18: 1 \omega 9$ & $15.6 \pm 4.8$ & $3.8 \pm 2.2$ & $6.2 \pm 0.8$ & $1.9 \pm 1.5$ & $4.3 \pm 3.6$ & $1.1 \pm 0.7$ \\
\hline $18: 1 \omega 7$ & $0.7 \pm 0.2$ & $7.2 \pm 2.8$ & $5.8 \pm 1.7$ & $8.7 \pm 2.6$ & $7.2 \pm 4.1$ & $8.9 \pm 3.6$ \\
\hline Others (\%) & $2.8 \pm 0.2$ & $1.3 \pm 0.7$ & $4.1 \pm 1.4$ & $2.6 \pm 0.5$ & $3.2 \pm 1.6$ & $1.5 \pm 0.7$ \\
\hline Sum (\%) & $19.6 \pm 3.7$ & $13.6 \pm 6.1$ & $14.9 \pm 3.6$ & $16.1 \pm 7.2$ & $15.3 \pm 2.2$ & $11.1 \pm 2.8$ \\
\hline \multicolumn{7}{|l|}{ PUFA } \\
\hline $16: 2 \omega 4$ & $5.9 \pm 2.1$ & $7.7 \pm 2.0$ & $3.2 \pm 1.6$ & $1.1 \pm 0.8$ & $3.2 \pm 1.3$ & $0.9 \pm 1.3$ \\
\hline $18: 2 \omega 6$ & $1.2 \pm 0.9$ & $3.2 \pm 1.8$ & $5.2 \pm 1.9$ & $2.1 \pm 0.6$ & $6.4 \pm 4.0$ & $8.8 \pm 3.5$ \\
\hline $18: 3 \omega 6$ & $0.9 \pm 0.6$ & $1.8 \pm 0.6$ & $0.7 \pm 0.2$ & $1.3 \pm 1.0$ & $1.7 \pm 0.7$ & $3.4 \pm 0.5$ \\
\hline $18: 3 \omega 3$ & $1.1 \pm 0.7$ & - & $0.3 \pm 0.5$ & - & - & - \\
\hline $20: 4 \omega 6$ & $2.6 \pm 1.4$ & $6.2 \pm 2.9$ & $8.4 \pm 4.2$ & $9.5 \pm 7.3$ & $11.4 \pm 6.1$ & $7.9 \pm 3.7$ \\
\hline $20: 5 \omega 3$ & $9.3 \pm 2.5$ & $3.5 \pm 0.8$ & $13.6 \pm 3.5$ & $11.4 \pm 6.2$ & $14.1 \pm 0.5$ & $13.8 \pm 4.1$ \\
\hline $22: 6 \omega 3$ & $24.7 \pm 7.8$ & $13.7 \pm 4.7$ & $3.1 \pm 0.7$ & $1.4 \pm 0.7$ & $0.4 \pm 0.1$ & $1.1 \pm 0.9$ \\
\hline Others (\%) & $1.3 \pm 0.9$ & $1.8 \pm 0.6$ & $0.7 \pm 0.1$ & $1.5 \pm 0.8$ & $0.0 \pm 0.0$ & $1.5 \pm 0.7$ \\
\hline Sum (\%) & $47 \pm 11.6$ & $37.9 \pm 8.9$ & $35.2 \pm 9.3$ & $28.3 \pm 9.4$ & $37.2 \pm 11.4$ & $37.4 \pm 6.7$ \\
\hline \multicolumn{7}{|l|}{ LCFA } \\
\hline Sum (\%) & $2.4 \pm 1.8$ & $6.9 \pm 2.1$ & $9.9 \pm 2.7$ & $13.6 \pm 2.9$ & $8.9 \pm 3.6$ & $12.4 \pm 7.5$ \\
\hline $\begin{array}{l}\text { Total FAMEs } \\
\text { ( } \mu \mathrm{g} / \mathrm{g} \text { dry wt) }\end{array}$ & $1856.8 \pm 37.8$ & $1966.3 \pm 66.9$ & $2414.6 \pm 98.7$ & $2343.9 \pm 105.8$ & $3014.7 \pm 112.8$ & $3238.4 \pm 128.4$ \\
\hline
\end{tabular}

